\title{
WestVirginiaUniversity
}

THE RESEARCH REPOSITORY @ WVU

Graduate Theses, Dissertations, and Problem Reports

2020

\section{Gendered Access to Wetland Gardens (Dimba) in Northern Malawi}

\author{
Rhoda Nyirenda \\ WVU,rn0023@mix.wvu.edu
}

Follow this and additional works at: https://researchrepository.wvu.edu/etd

Part of the Human Geography Commons, and the Remote Sensing Commons

\section{Recommended Citation}

Nyirenda, Rhoda, "Gendered Access to Wetland Gardens (Dimba) in Northern Malawi" (2020). Graduate Theses, Dissertations, and Problem Reports. 7628.

https://researchrepository.wvu.edu/etd/7628

This Thesis is protected by copyright and/or related rights. It has been brought to you by the The Research Repository @ WVU with permission from the rights-holder(s). You are free to use this Thesis in any way that is permitted by the copyright and related rights legislation that applies to your use. For other uses you must obtain permission from the rights-holder(s) directly, unless additional rights are indicated by a Creative Commons license in the record and/ or on the work itself. This Thesis has been accepted for inclusion in WVU Graduate Theses, Dissertations, and Problem Reports collection by an authorized administrator of The Research Repository @ WVU. For more information, please contact researchrepository@mail.wvu.edu. 
Gendered access to wetland gardens (dimba) in northern Malawi

\author{
Rhoda Nyirenda \\ Thesis submitted \\ to the Eberly College of Arts and Sciences \\ at West Virginia University \\ in partial fulfillment of the requirements for the degree of \\ Master Arts in \\ Geography
}

Brent McCusker, Ph.D., Chair

Aaron Maxwell, Ph.D.

Jamie Shinn, Ph.D.

Department of Geology and Geography

Morgantown, West Virginia

2020

Keywords: Wetland garden, gendered access, proximity a stream, adaptation to climate change, household food security, land use land cover change

Copyright 2020 [Rhoda Nyirenda] 


\section{Abstract \\ Gendered access to wetland gardens (dimba) in northern Malawi}

\section{Rhoda Nyirenda}

Due to increasing degradation of upland fields and in the face of erratic rains and increasing occurrence of droughts and floods and increasing food prices, smallholder farmers in many places across sub Saharan Africa engage in wetland cultivation for livelihoods security (Mutambikwa et al., 2000). A cultivatable wetland area is considered prime land, and a desired opportunity that every rural family need for the purpose of food production. Studies have indicated that wetland cultivation significantly contributes to household's income and food security. Wetland agriculture, however, in Malawi and most of the sub-Saharan African countries is marred with issues of access to land (Simon 2014; Kambewa 2005). Employing mixed methods approach this study attempted to appreciate: 1) how dimba cultivation contribute to household food security and livelihoods resilience, 2) how gender influence access to wetland in Nkhata Bay, and 3) how does the geographic factors of proximity to stream/rivers affect ownership or access to wetland gardens? The study has revealed through exploratory analysis and statistical test i.e. ANOVA that there is significant difference in term of food security between households with dimba and those without dimba. Increase in spatial extent of dimba cultivation between 1990 and 2005 as reveled through land use/cove change analysis further indicates the significance of dimba in the study area. The study has further revealed that in Nkhata Bay, as a patrilocal system, wetland gardens are owned by men, women only get access through their husbands. Women's access to wetland gardens is further compounded by widowhood, and divorce. Most women lose access to wetland gardens or face challenges accessing wetland gardens when the husband dies. 


\section{Acknowledgement}

The success of this thesis is a result of the important role played by individuals and institutions. First and foremost, I would like to acknowledge my supervisor, Dr Brent McCusker, who through YouthMappers granted me Research Assistantship to study for MA in Geography at West Virginia University and do this research in Malawi. Without him I could not have stepped my feet in the USA let alone studying at WVU. God richly bless you Dr McCusker.

I am also grateful to my supervisor, Dr Brent McCusker for tirelessly guiding me in shaping this work. Many thanks also go to the thesis committee Dr Aaron Maxwell and Dr Jamie Shinn for their precious time and immeasurable help all through.

I would like to thank my husband Park, for tirelessly encouraging me when I reached a breaking point and taking care of our two beautiful daughters Lucy and Hope whenever due dates were very close. It could have been much harder without you Park. I am sincerely grateful.

To my daughters Lucy and Hope, I say thank you for giving me the laughter when I needed it most and the energy to forge ahead.

I would also like to appreciate my family, my mother Mercy Mapiri, my brothers and sisters for your prayers and support. My brother Abel Kwelani, I really appreciate for being there for me always. All the support and encouragement you rendered me in my life is greatly appreciated.

Finally, I would like to thank the enumerators who assisted in the field work and the farmers for participating in this research. I couldn't have done this without you. 
Table of Contents

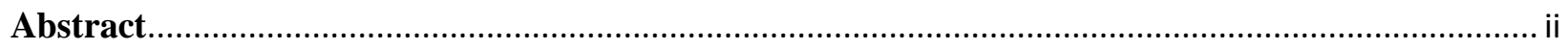

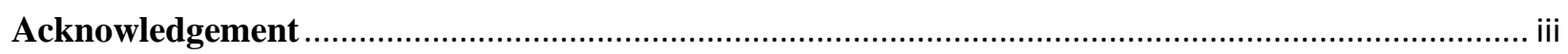

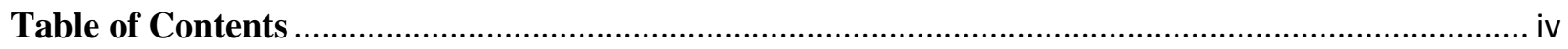

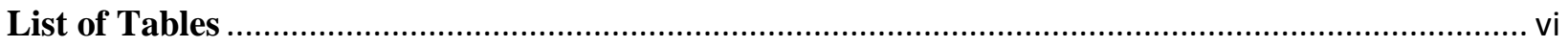

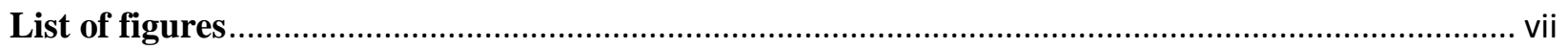

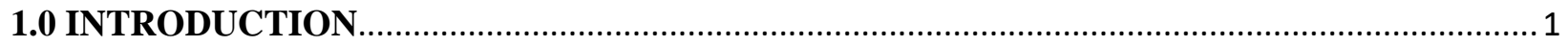

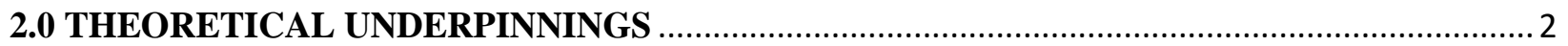

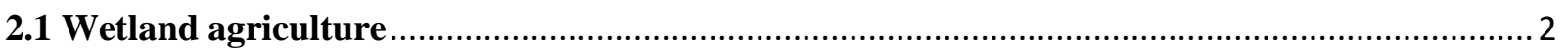

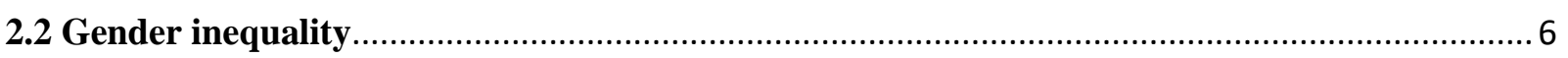

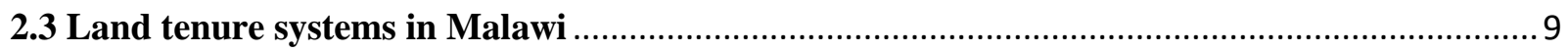

2.4 Land use land cover change detection/analysis .............................................................. 14

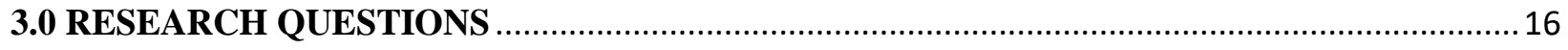

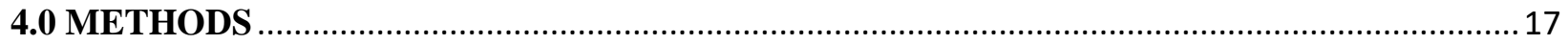

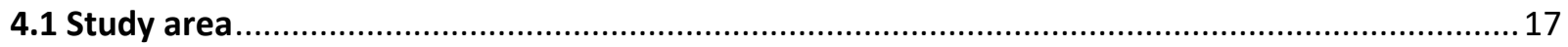

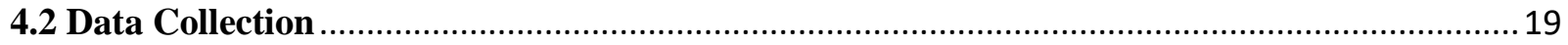

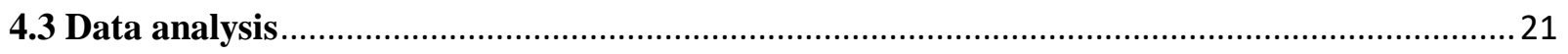

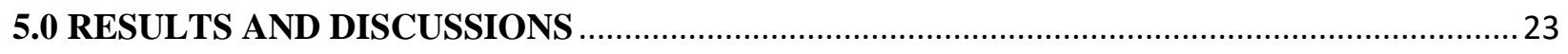

5.1 The role of dimba in improving rural livelihoods: difference between households with and

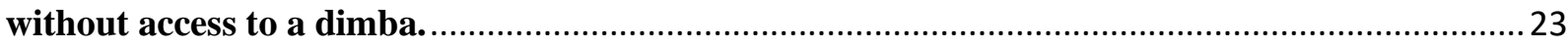

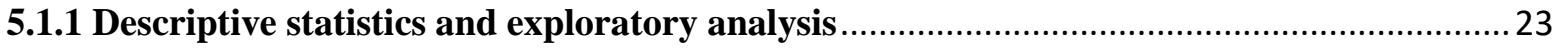

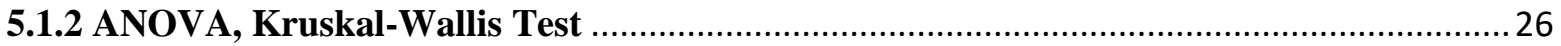

5.2 The role of dimba cultivation in food security and livelihoods adaptation to climate and

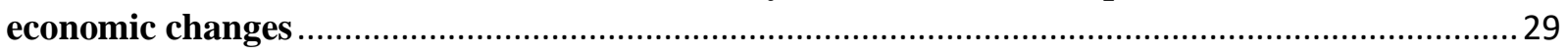

5.2.1 Contribution of Dimba to household food security and income .....................................29

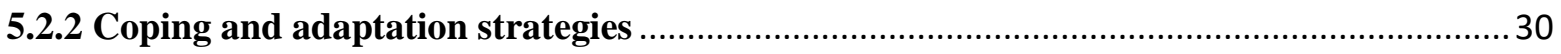

5.3 Ownership, access and use of dimba: gender and other social markers governing wetland

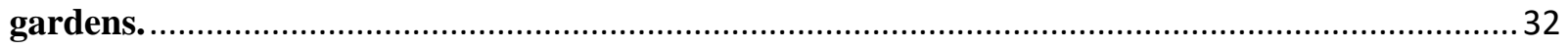

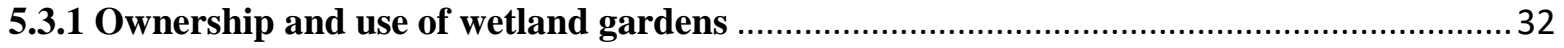

5.3.2 Control and use of income from dimba agriculture ...................................................... 34

5.4 Proximity to stream banks and ownership of wetland gardens ............................................ 34

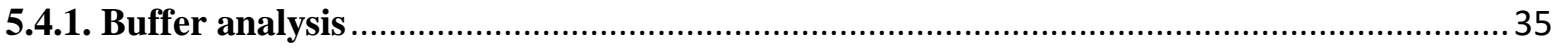


5.5 Extent and change in the wetland cultivation

5.5.1 Classification

5.5.2 Change detection - post classification analysis

5.5.3. Accuracy assessment 41

6.0 SUMMARY AND CONCLUSION. 42

7.0 RECOMMENDATIONS... .44

8.0. LIMITATIONS OF THE STUDY. 46

REFERENCES. .47 


\section{List of Tables}

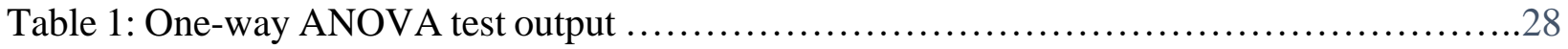

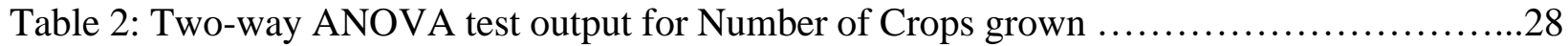

Table 3: Two-way ANOVA test output for Income from Agriculture........................29

Table 4: Two-way ANOVA test output for Months with Adequate Food ....................29

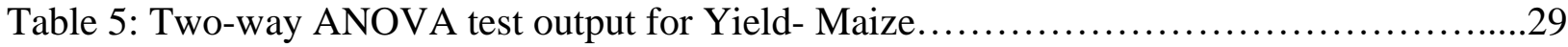

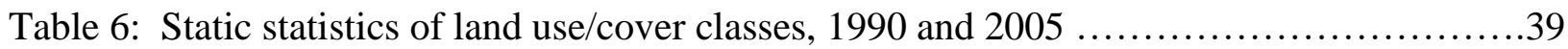

Table 7: Error Matrix for 1990 - 2005 change detection map..........................42

Table 8: Accuracy totals for 1990 - 2005 change detection map.........................42 


\section{List of figures}

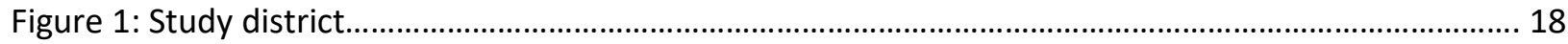

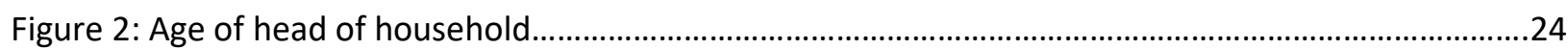

Figure 3: Participant's length of residence in the village

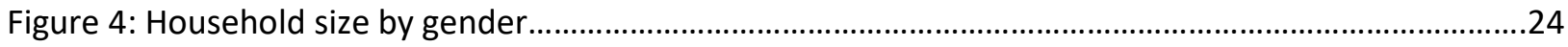

Figure 5: Respondents level of education by gender.......................................................................... 24

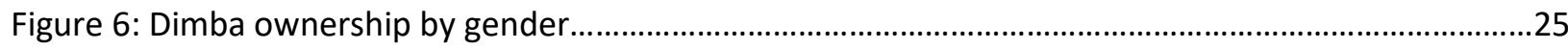

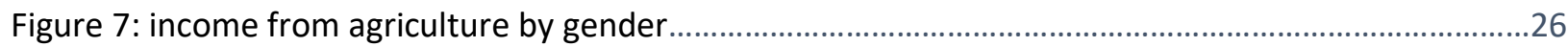

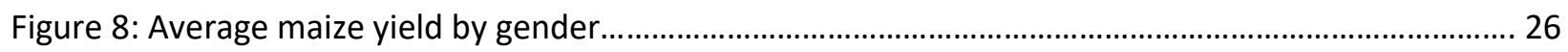

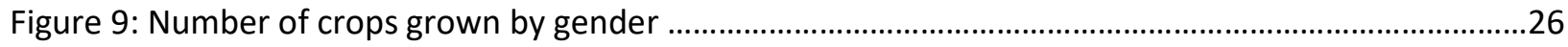

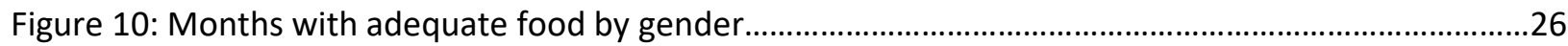

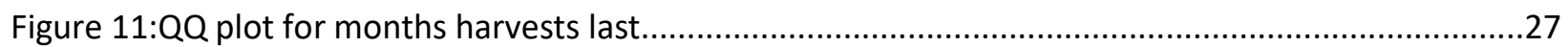

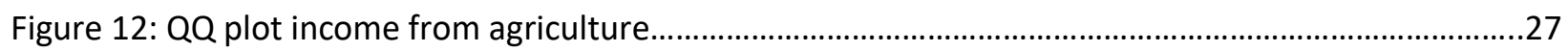

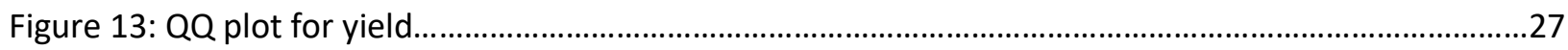

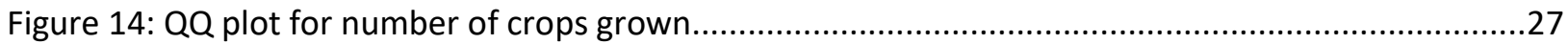

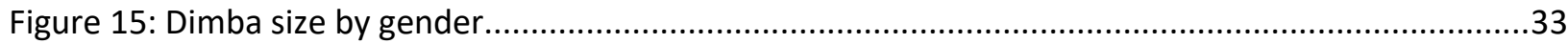

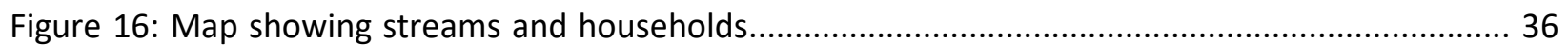

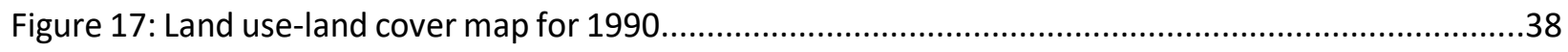

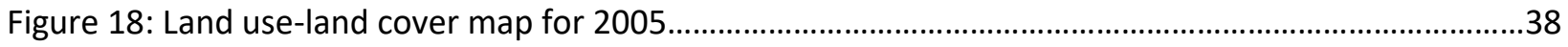

Figure 19: Summary of 1990 - 2005 land use/cover change …...................................................................40

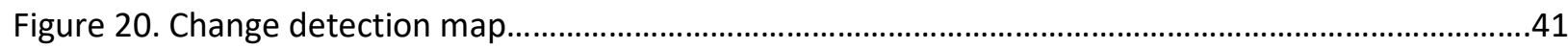




\subsection{INTRODUCTION}

Due to increasing degradation of upland fields and erratic rains, smallholder farmers in Africa have resorted to wetland cultivation for livelihoods security (Mutambikwa et al., 2000). In rural parts of sub-Saharan African countries such as Malawi, Zambia, Mozambique, Kenya, Tanzania, and Ethiopia, smallholder farmers are heavily dependent on wetland cultivation. Wetlands have been cultivated since 300AD due to their reliable water supply (Kotze et al. 2004). The practice has been developed by different people in different countries. A cultivatable wetland area is considered prime land, and a desired opportunity that every rural family need for the purpose of food production. Research conducted in Simlemba, central Malawi, indicated that wetland cultivation accounts for $37 \%$ of domestically consumed food and generates $55 \%$ of cash income per household (Msusa 2011). A similar analysis in Cyabayanga in Rwanda found that the per household contribution of wetland cultivation to gross margin was 74\% (Nabahungu and Visser 2011). In Tanzania, Mahenya (2008) found that the contribution of wetland cultivation to total household cash income was more than $60 \%$. Comparing production of upland fields and wetland gardens Nyamadzawo et al. (2015) observed that smallholder farmers in Zimbabwe harvest more from wetland gardens i.e. an average of 2-3 $\mathrm{t} \mathrm{ha}^{-1}$ than upland fields which yields less than $1 \mathrm{tha} .^{-1}$ And according to Dixon (2005) dry season cultivation of maize in the wetland has significantly helped smallholder farmers to survive the famous long "hungry" season in Ethiopia. This study used a mixed methods approach to understand gendered access to wetlands in northern Malawi as adaptation to climate change.

In Malawi, wetland agriculture takes place as formal schemes that include government irrigation schemes and informal irrigation, which include dimbas (smallholder wetland gardens). Estimates have shown that 123,000 ha are under informal cultivation compared to 27,000 ha under formal wetland irrigation (Kambewa 2005). Dimbas play a vital role in rural livelihood security and resilience to weather and economic shocks. Through dimba cultivation smallholder farmers can grow different crops more than once a year thereby improving rural income and food availability. In the face of increasing occurrence of droughts and floods and increasing food prices, dimba also act as a means of improving rural livelihoods resilience. Through dimba, smallholder farmers and communities survive long dry seasons and avoid seasonal hunger. 
However, wetland agriculture in Malawi and most of the sub-Saharan African countries is marred with issues of access to land (Simon 2014; Kambewa 2005). Although women are at the center of smallholder agriculture, particularly wetland cultivation, women's access to wetlands in terms of either customary law or formal law are nearly invisible in Malawi and southern Africa in general (Helliker and Murisa 2011). Existing modes of access, allocation, use and control over wetland gardens continue to ignore women. This is despite existence of the knowledge that if rural women had the same access to agricultural resources (i.e. land) as men, yield could increase by $20-30 \%$ and the total number of hungry people around the world could be reduced by 12-17\% (FAO 2012). It is against this background that I hypothesized that improving information about existing modes of access to wetlands is key to development and improvement of wetland cultivation and production and consequently to reducing rural livelihoods vulnerability.

Practically, this research project was rooted in a mixed method approach to study how access, control, ownership and use of wetlands as adaptation to climate change in Malawi is influenced/governed by social and power relation. The research was conducted in rural district of Nkhata Bay in northern Malawi. The study zeroed in on these specific questions: What governs ownership, access and use of dimba land at community level? What is the role of dimba cultivation in adaptation to climate change?/ How does dimba cultivation contribute to food security and livelihoods adaptation to climate change? Given that Malawi is exposed to frequent adverse climatic shocks, understanding of gendered access to wetland gardens will contribute to improving wetland cultivation and rural livelihoods.

\subsection{THEORETICAL UNDERPINNINGS}

Situated in mixed method approach, the study drew on a range of subthemes in the discipline of geography including remote sensing (i.e. change detection), gender, and wetland agriculture as adaptation to climate change.

\subsection{Wetland agriculture}

Wetland characterization in Malawi: Wetlands as defined by the Ramsar Convention (1971) are areas of marsh, fen, peatland or water, whether natural or artificial, permanent or temporal, with water that is flowing or static, fresh, brackish or salt, including areas of marine water the depth of which at low tide does not exceed six meters (Wood 2013; Simon 2014). According to Wood, 
(2013), the Ramsar 2009 classified wetlands into five categories, namely marine (coastal wetlandscoastal lagoons, rocky shores), estuarine (delta wetlands, mangrove swamps), lacustrine (wetlands associated with lakes), riverine (wetlands along rivers and streams-floodplain wetlands) and palustrine (marshes, swamps and bogs). Wood (2013) stated that all these types of wetlands are found throughout Africa. However, these wetlands are called different names in different parts of Africa. For instance, in west Africa, wetlands are called fadamas and in central Africa they are called dambos. Malawi as a country has several types of wetlands. For instance, lacustrine wetlands include those along Lake Malawi, Lake Chilwa and Lake Malombe; major marshes include Ndindi Marsh, Elephant Marsh and Vwaza Marsh; swamps include Bana Swamp and Dzenza Swamp, as well as those occurring along rivers and streams. River/stream wetlands are usually broad, gentle sloping valleys prone to flooding. Seasonal flooding increase soil fertility and moisture, and hence they are good areas for agriculture.

The wetlands discussed in this paper are those in the group of river/stream wetlands which locally called dambos These dambos total to 480,000 to 600,000 ha of irrigable areas in Malawi of which about $70 \%$ are upland dambos and about 25\% are floodplains. (Msusa 2011, Chidanti-malunga 2009).

Importance of wetlands: For a long time, wetlands were regarded as wastelands. But for many decades, wetlands have been recognized as areas rich in a range of goods and services valuable to human life. Recognizing the multifunctionality of wetlands, many authors have written about the value and functions of wetlands (c.f. Barbier 1994; Schuyt, 2005, Mwakaje 2009 Nabahungu and Visser 2011; Bosma et al 2017). According to Bosma et, al (2017), at a global scale, wetlands provide both direct and indirect benefits to people around them and those outside the periphery of the wetlands. Direct uses of wetlands are benefits provided by wetlands which are of direct use to people (Barbier 1994, Oglethorpe and Miliadou 2000) and these include cultivation, livestock grazing, fishing, hunting, as a perennial source of water for irrigation, source of medicinal plants, fuelwood among others (Barbier 1994; Oglethorpe and Miliadou 2000; Wang, 2006 Mwakaje 2009; Kotze 2011, Nabahungu and Visser 2011). On the other hand, indirect benefits of wetlands have been termed as functional services which reflect the indirect benefits provided by wetlands and they include, flood control, climate control, water regulation, water purification water storage, 
filtration, toxic retention and habitat for biodiversity both flora and fauna (Barbier 1994; Oglethorpe and Miliadou 2000; Mwakaje 2009, Wood, 2013).

Wetlands are found across Africa and they are very important for the survival of people. Wetlands in Africa directly contribute to people's livelihood. According to Wood (2013), marginal areas in Africa have for a long time directly depended on wetlands for food, water, fiber and fuel. As a source of food, wetlands in Africa support most rural people's livelihoods through subsistence farming (Kotze, 2011). In Malawi, households that have access to wetland gardens in the dry season normally have enough food for most of the year. Research carried out in two different parts of Malawi, the Lake Chilwa wetland in the southern part and in Ekwendeni in the northern part by Kambewa (2005) and by Kerr (2005) respectively, showed that most households that have access to wetland gardens in the dry season have enough food throughout the year. Kambewa (2005) in his study about access to and monopoly over wetlands in Malawi, specifically pointed out that $75 \%$ of all the people with wetland gardens around the Lake Chilwa wetlands were food secure throughout the year, making them hunger free in the months of January and February, a period of hunger for many Malawians as they wait for upland crops to mature.

Wetland agriculture as adaptation to climate change: With a lot of research on climate, scientists agree that globally climate is changing and will continue to change in the future (Fisher 2010). Globally, climate is projected to increase by $2^{\circ} \mathrm{C}-4^{\circ} \mathrm{C}$ by 2100 (IPCC, 2013). At a regional level, predictions indicate that southern Africa is warming at a range of $0.2^{\circ} \mathrm{C}$ to $0.5^{\circ} \mathrm{C}$ per decade, accompanied by extensive changes in precipitation (Hulme et al., 2001). For instance, a decrease in rainfall was observed between 1796 and 1996 (Neukom et al.,2014). Similarly, Jenkinsi et al (2002) reported that rainfall decreased substantially over the last 60 years. However, other studies have shown that southern Africa experiences more rainfall variability than change in total rainfall (Tadross et al., 2009; Rurinda et al., 2013). This includes longer delays in the onset of the rainy season and more frequent droughts. In general, southern Africa is projected to experience drier and more extreme conditions and an increased frequency of drought in the future (Wang 2005; Shefield and Wood 2008).

Recent climate trends assessments indicate that between 1960 and 2006, mean annual temperature for Malawi increased by $0.9^{\circ} \mathrm{C}$ with an average rate of $0.21^{\circ} \mathrm{C}$ per decade (Nkomwa, et al 2014). 
During this time, rainfall pattern also changed. According to McSweeney et al., (2008) monthly rainfall slightly decreased by $5.8 \mathrm{~mm}$ per month but the amount of rain on days with extreme rainfall increased while the number of days with heavy rainfall decreased. Widespread changes in temperature and rainfall pattern resulted in numerous weather-related disasters like droughts, dry spells and floods (Fisher 2010). Within the past decade they have been re-current, and they are predicted to continue in the future (Chidanti-Malunga 2009; Peters 2004). Floods and droughts have increased in intensity and frequency and have been associated with climate change (Msusa 2011; Chidanti-Malunga 2009). The situation has put agriculture at risk, adversely affecting the livelihoods of the rural masses who directly depend on rain-fed agriculture for food and income. For instance, flooding in 2001-02 and drought in 2005 caused chronic food shortages among other problems during those years. The resulting food crisis in these years, as well as in other years, reveals the fragility and vulnerability of rural agricultural livelihoods in Malawi to climate variability.

Climate change related stressors is one of the factors adversely affecting agricultural production, especially of maize, Malawi's staple crop. As a result, Malawi finds herself persistently vulnerable to food insecurity. Being a relative term, food security depends on food preferences of the majority in an area. Malawi's food security depends on adequate production of and access to maize (Kakota et al., 2015). Maize is widely cultivated and consumed across Malawi. In 2006, the Government of Malawi (GoM)pointed out that 80 percent of cultivated land is maize and accounts for over 50 percent of calories consumed.

To ensure food security in Malawi, increasing smallholder agricultural production is therefore inevitable. However, erratic rains, recurrent droughts, floods that have affected Malawi since the 1980s, and soil degradation in the uplands among other factors makes it hard for smallholder farmers to increase their production in the uplands. Wetlands being relatively fertile and moist in the dry season have now become alternative sources for crop production. Through the availability of water, nearly exclusively shallow wells and hand-watering are used to water the crops in the dry season (Simon 2014). Through watering, farmers can grow more than once in a year, offering them opportunity to supplement their meagre harvests from the uplands rain-fed crop production (Chinsinga 2007). In 2005, GoM reported that during the 2003/04 drought, many farmers across the county turned to wetlands where, using informal irrigation systems, they managed to produce 
the staple food, maize. During this drought year, the government of Malawi reported that maize yield under informal irrigation in wetlands was more than that under rainfed systems in the upland across the entire country. Crop production was higher per unit area in that year in the dimbas than in the uplands. With this scenario, one would therefore argue that when rain fails in Malawi, wetlands become important sources of crop production contributing significantly to household food security. Studies show that use of dimba as a livelihood adaptation strategy to climate change is spread across sub-Saharan Africa. For instance, in Zimbabwe Nyamadzawo (2014) noted that cultivation of wetlands presents a climate change and variability adaptation option for smallholder farmers. The Millennium Ecosystem Assessment (2005) noted that of late, wetlands are critical food security safety nets in many parts of sub-Saharan Africa.

In the face of economic shocks, dimbas have also become vital in improving rural household income and providing resilience. Winter cultivation in the dimbas help to produce foodstuffs such as vegetables, sweet potatoes, tomatoes, maize that have higher market price due to generally low supply (Simon 2014). By selling such foodstuffs, rural households are able to supplement their cash and improve their living standards and consequently alleviate rural poverty (Nkhoma 2003; Chinsinga 2007). In addition, wetland cultivation helps to lower household expenditure for those who do not sell much of their produce (Simon 2014). Household income is therefore not spent on foodstuffs produced in the wetland gardens.

Although some studies have looked at the issue of access in wetland agriculture (e.g. Simon 2014; Kambewa 2005; Peters and Kambewa 2007), I found no study that explicitly included spatial analysis or space as a theoretical construct upon which access to wetland gardens should be examined. The traditional non-spatial approaches to analyzing access to wetland may not be sufficient for elucidating existing modes of access, control, and ownership or use of wetlands. With spatial analysis, one can understand the extent of wetland cultivation and appreciate how geographical factors such as proximity to rivers/streams can affect access to wetland garden.

\subsection{Gender inequality}

The concept of gender: Gender means different things to different people. However, briefly gender can be defined as the social construction of what it is to be female and male in any given society at any given time (Alston 2013). This social construction entails what is expected of men 
and women in terms of their roles and how they relate. Different societies in the world have different expectations, roles for men and women. These differential expectations, roles tend to put men at a position with greater access to power and resources than women resulting to gender inequalities. This often puts women at a disadvantaged position. According to Denton (2002), estimates suggest that women own about $1 \%$ of the world's resources earn $10 \%$ of the world's income and occupy about $18 \%$ of seats in the world's parliaments. Denton (2002) further said gender inequalities are prevalent in developing countries, such as those in sub Saharan Africa.

2.2.1 State of gender inequality in Malawi: Malawi like other sub Saharan countries faces gender inequalities. Women continue to be marginalized in several areas/sectors. The UNDP 2010, report on indicators of gender inequality revealed that one of the Millennium Development Goals (MDGs) that is likely to be missed by Malawi is MGD 3 - Promote Gender Equality and Empower Women. Likewise, in 2010, the Ministry of Gender, Child and Community Development, reported that Malawian women are doing poorly in economic and political power. The ministry further said significant disparities between men and women are in higher education, paid employment, as well as in leadership positions in all sectors of society. Additionally, the ministry highlighted that these and other sectors in Malawi are important for human well-being, productivity, and economic growth. Gender inequality in different sectors therefore matters a lot. In order to understand the extent of gender inequality in Malawi, the following paragraphs reviews the differences between men and women in various sectors.

Economically, there is unequal access to opportunities between men and women in Malawi. This is due to several factors such as lack of access to financial capital and their low education levels (Loscocco et al. 1999). According to the 2008 National FinScope survey report, many women, especially rural women, have less access to microfinance services. Statistically, the 2005 Integrated Household Survey indicated that only $11 \%$ of rural women access loans from microfinance lending institutions compared to $14 \%$ for men. This lowers women's ability to invest in business activities (Loscocco et al. 1999). Similarly, low education levels for women limit their employment opportunities and also lowers their outcomes in business performance (Loscocco et al., 1991). 
Unequal participation of men and women in politics is another evidence of gender inequality in Malawi. Historically, Malawi politics has been dominated by men both at national and local levels. Partly this is because of Malawi's failure to adopt innovative strategies such as gender budgeting initiatives or quota systems; multiple gender roles for women which make them work longer and more days; lack of support and co-operation from male colleagues; politics perceived as a space for men; and political parties nominating less women candidates (Tiessen 2008; UNDP 2001; Chiweza 2016; Kayuni and Chakadza 2016). Kayuni and Chakadza (2016) highlighted that voting for women in Malawi is largely dependent on women nominees presented by political parties. Analyzing the trend from 1994 to 2014 they found only a slight difference deviation between those women nominated and women elected.

Similarly, the two local elections that have happened in Malawi, thus, in 1998 and 2014, indicate a low but steady increase in women nominees and women elected in local government. According to Chiweza (2016), women representation in local government for 1998 and 2015 was $8.1 \%$ and 13. $4 \%$ respectively. In addition to women's underrepresentation in the national parliament and local government, location of women seats in the parliament also indicate gender inequality. According to the 2005 UNDP report, all women occupy the lower chambers in parliament. Though, women participation in politics is steadily increasing, their overall number remains low when compared to other African countries like South Africa, Mozambique and Rwanda (Phiri 2004; Tiessen 2008).

Differences in employment, education and higher positions in public service and industry between men and women is another evidence of gender inequality in Malawi. The male-female ratio in these sectors also favor the male gender. Women are marginalized in the formal employment. According to the National Statistics Office (NSO) 2013 labor force survey report, formal employment rate for women was $6.4 \%$ while men's rate was $16.2 \%$.

Females receive less education than males. For instance, in 2010, 19\% of women in Malawi were reported to have never attended school, compared with 11\% of men (NSO 2010) indicating a lower literacy rate for women ( $81 \%$ ) compared to $89 \%$ for men at national level. Educational differences between males and females in Malawi widens as one goes up the education ladder. For instance, with free primary education, enrolment for boys and girls is almost equal in primary school but differ in secondary and tertiary education (Ministry of Education, 2009). The UNESCO Institute 
of statistics, 2015 indicated that in 2012 secondary school enrollment for males was $36.05 \%$ while ratio for females was $32.41 \%$ and in tertiary education, the ratio for males was $0.99 \%$ and females ratio was $0.64 \%$

Differences in education, especially higher education results in differences in professional/ higher positions. For instance, Minton and Knottnerus (2008) noted that as of 2004, only 3\% women were employed in professional, technical or managerial positions while men totaled $8 \%$ in the same positions in the same year. On the same vein, top most positions ( $\mathrm{P} 4$ and above) in the civil service is represented by only 10\% women (Mbilizi and Aselele 2013) and in 2011 there were only 3 female justices out of the 27 justices in the high and supreme courts (The US Department of State 2011)

\subsection{Land tenure systems in Malawi}

The majority of Malawians depend on land for their livelihoods, employment and social security (Chinsinga et al 2013; Kishindo 2004). Estimates indicate that 84\% Malawians directly depend on land for agriculture which employs about $85 \%$ of Malawians (Chinsinga et al 2013). Access to land in Malawi therefore is vital as it is the source of livelihood of the majority. However, land is unequally distributed. Land tenure impacts land distribution in Malawi. The tenure system in Malawi dates to the British government. Under this colonial government, land was categorized into three categories: public, private and customary land. When Malawi attained independence in July 1964, the same land tenure system was adopted. Even with the political transition from a oneparty system to multiparty democracy in 1994 land tenure system remained the same up until 2016. However, the change mainly was that categories of land were reduced to two: private and public land. The intricacies about the distribution of land among the different social groups i.e. men and women were not adequately addressed. Further, wetlands are also not adequately covered. This section briefly reviews land tenure system in Malawi with regard to colonial period, post-colonial period, wetlands, and gender.

Colonial land tenure: During the colonial period land was categorized as public, private and customary. Private land meant all land that was owned, held or occupied under a freehold, leasehold, or a certificate of claim (Chirwa 2004). Examples to this category included cash crop estates like tea, sugar, coffee, tobacco estates. It was restricted to white settlers who did estate farming. Public land meant land occupied, used or acquired by the government and any other not 
being customary or private (Chirwa 2004). On the other hand, customary was land for use by indigenous people. However, under the British colonial law indigenous people had no formal title to land because customary land was vested in the Secretary of State who was mandated to administer it to the "natives". The colonial state favored private land owners (white settlers) because they promoted the colonial agenda of creating a 'capitalist' economy based on estate (or large scale) agriculture (Deininger and Xia 2017). This led to conversion of indigenous land holdings into private land because customary land was assumed to have zero value (Msisha, 1999). Thus, private land owners (white settlers) had preferential access to land than the indigenous people (Mataya and Tsonga 2001).

Post-colonial land tenure: After independence, Malawi adopted the English-based Land Act (Chinsinga et al 2013). The 1965 Land Act maintained the colonial categories of land, thus, private, public and customary land. The 1965 Land Act recognized customary land as the undoubted property of the people of Malawi (Silungwe 2005). However, the law vested customary land in the president in perpetuity and empowered the traditional leaders to allocate land to families/individuals in their areas. Under the law, the people of Malawi had no enforceable land rights but right of use and occupancy only (Silungwe 2005). Customary land tenure continued to be assumed insecure. It was perceived as a reserve from which private land was created to further the post-colonial government (under Hastings Kamuzu Banda) development policy of improving agricultural production through estate agriculture. Among the three land categories, customary land dominates in Malawi. According to Fisher and Kandiwa (2014) customary land accounts for $80 \%$ of the country's total land and supports most of the smallholder farmers. It is on customary land where issues of access are critical.

The 1965 Land Act was the law up until 2016 when a new Land Act was enacted. The 2016 Land Act also recognizes two categories of land: private and public Land. In the 2016 Land Act, private and public land did not change their meaning. On the contrary, customary land tenure is not recognized in the 2016 Land Act. In order to 'secure' the customary land holders through titling and registering customary land, the Act categorizes customary land as either private, (customary estate/registered customary land) or public (unallocated /unregistered customary land) (Chikosa 2009). The 2016 Customary Land Act disempowers chiefs from allocating land to their community members. The Act places administration of customary land under a village land committee chaired 
by the chiefs. Similarly, the Act vests all land in Malawi in perpetuity in the Republic (2016 Land Act; section 8) and not in the president. However, on the ground titling and registration of customary has only just started in 2019 in four districts.

Land tenure in the wetlands(dambos): Generally, the land tenure system in Malawi does not distinguish wetlands from other types of land use. No clear distinction is made between upland areas and the wetland (dambo) areas in the land laws. Dambo land is at a critical juncture because it is highly demanded for cultivation. According to Kambewa (2005), Malawi like many other SADC countries lacks wetland policy. Even the 2002 land policy made few references to wetlands (dambos) assuming them to be 'common access' or 'public land within the overall category of 'customary' tenure (Peters and Kambewa 2007). The 2016 Land Act also does not come out clearly on wetlands. Considering that there are only two categories of land in the 2016 Land Act, wetlands can therefore be assumed as either private or public depending on whether they are registered or not.

Land tenure and gender: From a gender perspective, land tenure in Malawi is not gender equitable. The Land Acts obscure the element of gender in land issues. For instance, the 1965 Land Act was gender and class blind (Chikosa 2009). These were entrenched further by the 1967 land reforms. According to Kanyongolo (2013), the 1967 land reforms instead of facilitating the transformation of class and gender inequalities in land issues, they benefited only people who had the purchasing power of leasehold or freehold titles to land. Likewise, the land reforms during the multiparty era do not clearly show gender equality. They give a simplified picture of land rights. For instance, the 2002 land policy simply stated that

"the guarantee of security of tenure shall be 'without any gender bias [or] discrimination to all citizens' under section 28 of the Constitution”.

Similarly, the 2016 Land Act, section 22 simply states that

"equality shall be ensured by not favoring certain groups of people and adopting no adverse discriminatory practices towards any person who has applied for a customary estate."

These assurances do not represent the practical enormous complexity of land rights. A vast range of traditional systems of land ownership and control which overlap with the officially recognized 
land tenure system (Ellsworth 2004) are left out. The traditional tenure systems often fail to recognize women's rights, particularly in patrilineal societies. Even in matrilineal societies, the WLSA study on Women and Land in Southern Africa revealed that women land ownership in matrilineal societies is theoretical, while practically, maternal uncles have power and controls over it (WLSA 2000). This is why under de facto position, women do not enjoy equal access to/ownership of land due to biases by land administrators though the land law gives both men and women de-jure access and control to land (Mbaya 2002).

Gender and access to and control of land: Like many African countries, Malawi's major form of agriculture is smallholder. Smallholder agriculture is affected by access to land and labor, the major agricultural inputs. However, to appreciate the implications that gender has on agricultural production in Malawi, one needs to understand the livelihood roles of men and women and how men and women have differential access to land and labor for agriculture.

Most smallholder agriculture in Malawi utilizes customary land. Customary land is titled by the Government of Malawi but administered through traditional authorities to individuals and families. However, customary land is not equally distributed between men and women. Matrilineal and patrilineal cultures determine ownership and access to land. In matrilineal culture, mainly practiced in the central and southern region, women own land through inheritance from their mothers, while males do not own land but only access it through marriage. On the other hand, in patrilineal culture, which is practiced in the northern region where the study was conducted, land is owned by men through inheritance. In this culture, women do not own land but access it through marriage. In cases of divorce, women lose access to land as men are the primary heirs. As a result, rights to cultivation are invested in men. This has a measurable effect on food security given that men decide what type of crops to be grown on their land and they tend to favor cash crops. When these crops are sold, husbands do not always remit income to the household for cooperative decision making. This was observed by Kerr (2005) in Ekwendeni in the northern Malawi. In her study, Kerr (2005) also observed that women received less support from kin like land, cash and food and that they enjoy little or no access to household income.

Gender and agricultural labor: Due to the widespread poverty of smallholder farmers, most use simple tools, such as hand-hoes, to cultivate their farms. Use of hand-hoes and application of 
fertilizer and harvesting demands a large supply of labor, which is mostly provided by family members. Labor therefore becomes an essential input in agriculture. However, accepted gender roles influence gender division of labor in agricultural production (Karamba and Winters 2015) especially in societies where men and women perform different tasks or have differential access to household or hired labor (Fisher and Kandiwa 2014). In cases where men and women perform different tasks, women split their time between home production and agricultural production. Within the household, rural Malawian women usually perform more domestic reproduction tasks than men. They are culturally expected to look after children, the sick, and the elderly and fetch water and firewood and carry out other household chores. Such unshared household tasks hamper women's participation in agricultural production or participation in paid employment (Karamba and Winters 2015). This may lead to poor harvests as women cannot carry out all their agricultural activities and cannot buy fertilizer as the money is spent on caring for the sick (Kerr 2005). This becomes worse for women who are in polygamous families. Women in such families are also expected to provide agricultural labor to their husbands or sons making men have greater access to labor than women.

Apart from gender differences in agricultural labor within the households, studies have revealed that gender differences on agricultural labor also exist between female-headed households and male-headed households (Kassie et al 2013; Fisher and Kandiwa., 2014). Male-headed households have a higher access to agricultural labor than female-headed households. This was attributed to social norms and access to income. Through social norms, men have command over labor of their wives and female kin, however, female household heads do not have reciprocal command over their male kin for labor. In terms of access to income, male-headed households have greater access to cash than their counter parts. This enables the male household heads to hire labor. Female household heads often have less income due to financial distress after the death of a male head of household or loss of a productive household member (in case the head of the household was a widow) (Kassie et al 2013). However, these gender inequalities are not linear, they are linked to other forms of gender inequalities. These inequalities put females/female headed households at risk of reduced income and food insecurity than male headed households since few productive agricultural resources are made available to them. 
Why gender and wetland agriculture? For more than a decade now, it has come to the attention of development practitioners and policy makers that gender plays an important role in development (Kassie et al 2013, FAO 2011, World Bank 2009). Gender inequalities have been recognized to impede development (Kassie et al 2013). In search of means to reduce food insecurity and poverty in sub Saharan Africa, addressing gender inequalities have been argued to be one of the ways that can help to achieve food security and alleviate poverty. Many gender issues have been discussed in agricultural production, but little is known about contribution of gender and wetland agriculture to food security. As discussed above, women farmers form an integral part of smallholder agriculture, contributing about 50\% - 70\% of agricultural labor in sub Saharan Africa, Malawi in particular, but their access to productive agricultural resources like land and labor is unequal to mens' access to the same resources.

Regarding smallholder wetland agriculture, women are usually confined to food crops that are usually grown on small plots due to lack of access to land, labor, and other inputs like fertilizer. Given equal resources as men, women have the potential to increase their income and production by more than $20 \%$ (Kiptot, E et al, 2014). With the increased production, hunger can be reduced in the sub Saharan Africa and Malawi in particular.

\subsection{Land use land cover change detection/analysis}

In order to appreciate the extent of wetland cultivation in the study area, the study also involved land use and land cover change analysis in Nkhata Bay.

Land use and land cover change: Land cover refers to natural and human features on the surface. On the other hand, land use, can be described as activities taking place on the land (Fonji and Taff, 2014). Jointly land use/land cover loosely refers to the physical cover and human imprints on the land. Changes to land cover are to a larger part due to human modification through use. Land use and land cover changes can have consequential impact on the ecosystem and human wellbeing (Were et al. 2010). Though land use land cover change is local and place specific, collectively these changes add up to global change which adversely affect the functioning of the earth as a system.

According to Abbas (2012), land use/land cover change represents the changes that occur over the cover as a result of human modification of its uses. Understanding of land use and land cover and 
its dynamics is central to achieving the goals of sustainable development and effectively mitigating and adapting to global environmental change. This, however, requires accurate and reliable land use land cover information at different scales: spatial (local to regional/global) and temporal (past and present). Remote sensing seems to be the practical means of generating land use land cover information; particularly that land use land cover data is not available in most areas.

Role of Remote Sensing: Land use land cover and change can be detected through a variety of methods. Field observation and aerial photographs are some of the traditional means to map land use land cover change. While these traditional methods are useful and cannot be eliminated, they have a number of limitations. It is more costly and time consuming using traditional methods to conduct land use land cover and change studies with a bigger study area. In addition, many remote areas in developing countries are hard to reach (inaccessible), and it (has) is particularly difficult to get land use land cover data using the traditional methods such as field observation. Further, with rapid environmental change (i.e. deforestation, land degradation) taking place in most developing countries it has become much difficult to capture and generate accurate and reliable land use land cover information using traditional methods.

On the other hand, timely and adequate data is required for meaningful land use land cover and change information that can effectively guide decision making. There is a dearth of land use land cover and change data at appropriate spatial and temporal scales in most developing countries. Satellite imagery offers a promising means to study land use land cover changes because images can cover large geographic extents and temporal coverage. Were et al. (2013) argue that remotely sensed satellite imagery seems the only practical means of providing complete, spatially explicit, accurate and cost-effective time series data for mapping and monitoring the spatial and temporal land cover land use dynamics. Since 1972 (launch of Landsat 1) remotely sensed data has been applied in the study of different land cover types: mountainous regions, urban areas, estuarine areas, wetlands, forests, savannas, dry lands, river deltas, coastal zones and agricultural area. With many years of archived satellite data, it is now possible to analyze the land use land cover trends and modeling future conditions. It is now possible with satellite remote sensing to analyze largescale patterns. 
Limitations: While space borne remote sensing plays a tremendous role in providing timely and meaningful information for land use land cover and change initiatives, it is not without limitations. To begin with, space borne remote sensing cannot be used all alone, without combining it with the traditional methods in land use land cover and change studies. As pointed out by Fonji and Taff (2014) satellite imagery can identify land cover, inferring land use however requires more knowledge of the study area which is only possible with the traditional methods. When used all alone therefore compromise is made in identifying in the variable of interest (land use).

This is well illustrated in the land cover mapping in the upper Shire River catchment in Malawi using Landsat satellite data. Palamuleni et al 2010 pointed out that due to spectral similarity of some land cover classes i.e. built up areas (especially grass-thatched) and cultivated areas/grazing, mapping of the upper Shire River catchment area from satellite imagery was challenging. Palamuleni et al 2010 said that built up areas (especially grass-thatched) and cultivated areas/grazing occur in similar environments and are often in adjacent or mixed stands. During the dry season when there is little chlorophyll in the vegetation, grazing causes exposure of soil between remaining vegetation. This resulted in similarity between spectral values of grassthatched built-up areas and cultivated/grazing fields, making it difficult to distinguish (Palamuleni et al 2010).

Secondly as summarized by Fonji and Taff (2014) general limitations of remote sensing include: the inability of many sensors to obtain data and information through cloud cover, distinct phenomena can be confused if they look the same to the sensor, the resolution of the satellite imagery may be too coarse for detailed mapping and for distinguishing small contrasting areas and very high-resolution satellite imagery are very expensive.

Other concerns with use of remote sensing in land use land cover change pertain to classification. Although there are many classification systems for extracting land use land cover information from remotely sensed data, there is no single internationally agreed upon system. Use of current classification systems is consequently limited as they cannot be applied to other places.

\subsection{RESEARCH QUESTIONS}

This study investigated the following questions in order to understand gendered access to wetland gardens and their contribution to rural livelihoods in Nkhata Bay, northern Malawi. 
1. What governs ownership, access and use of dimba land at community level?

2. How does dimba cultivation contribute to food security and livelihoods adaptation to climate and economic changes?

3. Does the geographic factors of proximity to stream/rivers affect ownership or access to wetland gardens?

\subsection{METHODS}

In order to answer these research questions, a mixed methods approach was used. A mixed methods approach is commonly used in geography (e.g. Zimmerer, 2003; Carvalho and White 1997; Laws et al. 2003). In this study, mixed methods helped to better understand the implications of gendered access to wetland gardens on people's livelihoods, adaptation to climate shocks and social conditions/vulnerabilities.

\subsection{Study area}

The research was conducted in Nkhata Bay district in northern Malawi (e.g. Figure 1 below). Nkhata Bay district covers a total area of $40,071 \mathrm{~km}^{2}$, approximately 15 percent and 4 percent of the Northern Region and national land area respectively. Nkhata Bay is characterized by rocky soils and rugged terrain covered with forest. It comprises an escarpment leading down from the Viphya Mountains to the lakeshore. Elevation ranges from $450 \mathrm{~m}$ to $1,900 \mathrm{~m}$ above sea level. Lithosols (shallow and stony soil) mainly occurring on steep slopes are the most predominant soils in Nkhata Bay District. Black wet clay soil suitable for rice and sugarcane cultivation are found along wetlands e.g. Limphasa wetland. 


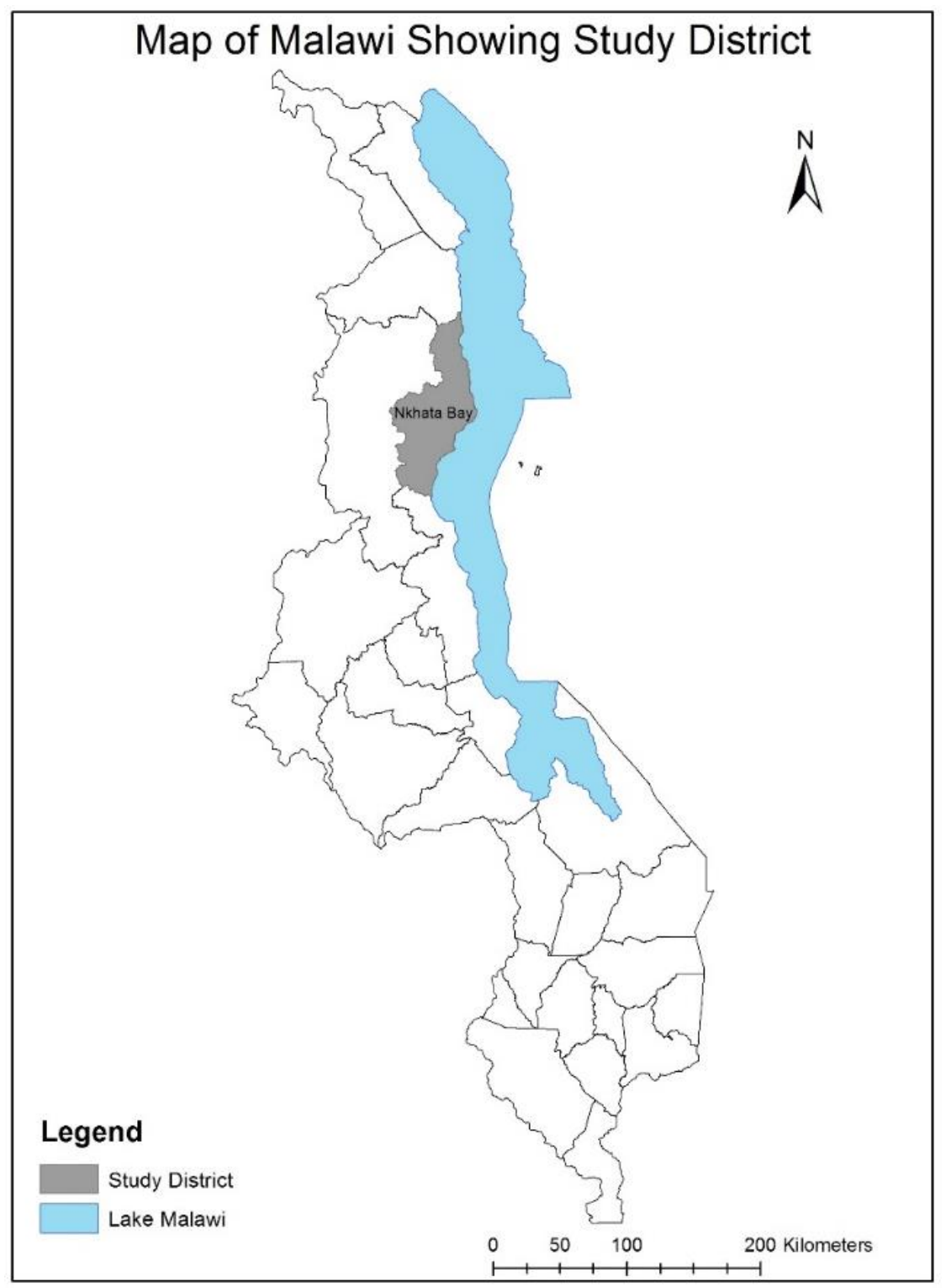

Figure 2: Study district

Nkhata Bay like the rest of the country is in the warm tropical climate zone. Compared to other parts of the country, it has a fairly moist climate. It experiences both convectional rainfall and topographic rainfall. Total average annual rainfall is approximately $1,900 \mathrm{~mm}$. Some places along the Viphya plateau have a rainforest climate. Average temperature ranges between $20^{\circ} \mathrm{C}$ and $28^{\circ} \mathrm{C}$. Low temperature is experienced between June and July and high temperature is experienced between November and December. With high rainfall but poor soils, cassava is the dominant crop in the area. Maize, sweet potatoes, rice, and bananas are also grown. Besides agriculture, petty trade (i.e. selling local alcoholic drink, fuel wood, charcoal to supplement household incomes), 
forestry and fishing (for communities along Lake Malawi) are the main livelihood sources. Fishing is undertaken throughout the year, but peaks from mid-November to March following the rains

In Nkhata Bay district, as in much of the country, agriculture is predominantly rain-fed. Very few households have access to irrigation and non-farm income to supplement their existence. Smallholder agricultural livelihoods in the district are faced with environmental challenges such as droughts and floods, land degradation and declining soil fertility. Socioeconomic and demographic constraints also aggravate the livelihood challenges. Like most parts of the Northern Region, Nkhata Bay area is largely rural (not urbanized) and commercially isolated with poor road network. It is one of the country's hard to reach areas and there are limited markets for the agricultural produce i.e. bitter variety of cassava grown in the district.

Nkhata Bay district has a total population of about 215,789 people, out of which 49 percent are males and 51 percent are females (National Statistics Office, 2008). Average household size is 5.1 which is higher compared to national average of 4.4. Tonga and Tumbuka are the major tribes culturally. Tonga are both matrilineal and patrilineal while Tumbuka are patrilineal. Land allocation is under the traditional/customary tenure system. Cultivation rights, rather than ownership, is granted by the chief through the village headman. Among the Tumbuka, under the patrilineage system cultivation rights are inherited by the husband. Among the Tonga, cultivation rights are inherited by either the husband or wife.

Nkhata Bay makes ideal case study for studying access to wetland gardens as it has contrasting local cultural and natural environment conditions. Though Nkhata Bay district is endowed with perennial streams and wetlands and the district is characterized by poor stony soils only less than one percent 55,781 farm families have access to wetlands and stream banks for fertile soils and irrigation. While the three communities may be suitable for comparison study, the focus is to explore and identify a range of social, political and structural conditions/characteristics that influence access to wetland gardens. The wide variety and different types of land inheritance systems also allowed for scalability of the results of the study to the rest of the country.

\subsection{Data Collection}

Household survey: A household survey was conducted to generate quantitative and qualitative data regarding ownership, access and use of dimba land at village level and community level. 
Households social and demographic characteristics such as household size, households' heads, gender and other social markers like age, income levels, ethnicity, marital status and migration status was gathered. The household survey was also used to gather information about the influence of the geographical aspect of proximity to stream banks. To ensure adequate representation of all the three communities were purposefully identified in the study site. To cover wide range of agroecological and livelihoods variations, three communities were selected in the study site. The author conducted 135 interviews with household heads (90 males and 45 females) in Kavuzi, Mpamba and Sanga. The interviews were conducted in the local language.

Qualitative interviews (FGDs): Focus group discussions were conducted to gain an in-depth understanding of ownership, access and use of dimba land at village level and community level and association with vulnerability and adaptation to climate change in the study site. FGDs targeted specific sub-samples of the population (i.e. female and males separately but simultaneously). In total, 18 FGDs were conducted, 6 in each community. Discussions were facilitated by the author as she is conversant with the local language and culture. Discussions generally took about two hours each. FGDs have been argued to be the most commonly used methods of gathering qualitative information at a deeper level of understanding and for shared experiences. Thus, through FGD the author gained a more balanced view of issues, depth and richness in understanding of the of ownership, access and use of wetland gardens and impact on vulnerability and adaptation to climate change in the study site.

Satellite imagery: Landsat 5 Thematic Mapper TM (WRS 2 Path 168, Row 068) acquired on $10^{\text {th }}$ October 1990 and $9^{\text {th }}$ September 2005 were downloaded from USGS archive (http://glovis.usgs.gov) and processed using ERDAS Imagine software. The two data sets were selected because of free accessibility, free cloud cover and have close calendar dates. Similar/close calendar dates help to reduce the effects of season on land use/cover change (Srivastava et al 2012) and differences in amounts of haze and dust in the atmosphere (Berberoglu, and Akin 2009). The data sets were also considered appropriate because they were acquired in the dry season period for Malawi (May to October). This period marks the time for wetland (river/stream bank) cultivation. The dry period gives a higher potential for distinguishing crop lands along river banks from trees. 
Spatial data: Some streams of Mpamba and Sanga were mapped on Open Street Map (OSM). According to Lin (2015) OSM is an open source mapping platform aiming to provide a free editable world map by registered users. Kavuzi streams were not mapped because it was difficult to identify them on the image due to mountainous terrain and forests. Household coordinates were collected during household survey using iPhone 6 for every household interviewed According to Merry and Bettinger P (2019), smart phones work in similar way as an ordinary GPS unit in collecting GPS data as such they are used more often for data collection. Data collected through any GPS device including smart phones has errors such as positional errors. These errors are as a result of obstacles such as buildings, forests, mountains among others. In this study, positional error ranged from $7-10 \mathrm{~m}$.

\subsection{Data analysis}

Different but complementary data analysis techniques engaging qualitative and quantitative data were used to analyze collected data. A series of spatial analyses on the data generated through OSM and GPS points was conducted in a GIS environment to determine the spatial patterns of access, use, control and ownership to the dimba.

Qualitative data analysis: Qualitative data analysis involved organizing data into themes. Thematic data analysis was used to structure qualitative data to answer specific research questions. Coding, to sort and structure data, was done manually. Themes generated helped to directly answer the first research question which explored factors that govern ownership, access and use of dimba land at community level. Analysis drew on multi-scale themes (i.e. household and community) to uncover the underlying structures of ownership, access and use of wetland gardens. Central to the thematic analysis was gender analysis. Attention was paid to gender dynamics of ownership, access and use of dimbas. Gender was analyzed in relation to other social markers like marital status i.e age, income levels, ethnicity, marital status and migration

Quantitative data analysis: Quantitative data analysis involved use of descriptive plots e.g. mean, frequency and boxplots to explore, describe/summarize social and demographic characteristics such as household size, households' heads, gender and other social markers such as age, income levels, ethnicity, marital status ad migration status. To explore the role/ contribution of dimba cultivation to resilience to climate change comparison was made between households that have access to dimba and households that do not have access to dimba. The study included an ANOVA 
analysis on household survey data. The test was conducted to evaluate if the number of months the household has adequate food in a year, income from agricultural production, number and types of crops household grow and yield per year vary between households that have access to dimba and those that do not have access to dimba. Kruskal-Wallis test was used because the data nonparametric.

image analysis: Spatial data analysis involved classification and change detection of the satellite images. Land use/cover classification involved unsupervised method using ERDAS IMAGINE (2018) software. In unsupervised classification, the computer classifies the image by grouping pixels with similar spectral characteristics into clusters according to some statistically determined criteria (Jensen 2016; Warner et al., 2009). Unsupervised classification was chosen because of lack of ground reference data and the study area has undefined surface features (Jensen 2016). Change detection is a process whereby co-registered multi-temporal remote sensing data sets are used to determine change between dates of imaging. A number of change detection approaches are used in remote sensing. In this study, the post- classification change detection method was used to quantify land use land cover changes i.e. changes in river/stream bank cultivation in the study area from 1990 to 2005. According to Furkuor and Cofie (2011), post classification change detection involves independently classifying and comparing multi temporal images from different dates. With this method there is no need, at least in most cases, for atmospheric correction. There is also no confusion between different kinds of land cover change in the post classification product. Post classification as a change method goes beyond simple change detection, it attempts to provide detailed "from ... to" change, i.e. to quantify the change. However, some studies have pointed out that post classification change detection multiplies the classification errors (Jensen 2016; Warner et al., 2009), that is, classification errors of the individually classified images will be present in the final change detection thematic map. Images used for post classification must therefore be accurately classified.

Spatial data analysis: OSM data was exported into ArcGIS where together with household coordinates collected during household survey were used to conduct Euclidean buffer analysis to explore how geographical aspect of proximity to stream banks influence ownership, access and use of dimba land. 


\subsection{RESULTS AND DISCUSSIONS}

\subsection{The role of dimba in improving rural livelihoods: difference between households with}

and without access to a dimba.

Descriptive statistics, e.g. mean, frequency and box plots, were used to summarize/analyze household's demographic and socio-economic characteristics. This was done in order to explore and describe data. To capture the variations between households that have access to dimba and households that do not have access to dimba, the study conducted ANOVA analysis on household survey data. A nonparametric analysis of variance using a Kruskal-Wallis test was employed/used to evaluate if number of months the household had adequate food in a year, income from agricultural production, number and types of crops household grow and yield per year varied between households that have access to dimba and those that do not have access to dimba.

\subsubsection{Descriptive statistics and exploratory analysis}

The results of exploratory analysis indicate no remarkable gender differences in terms of length of residence (Figure 2). On the other hand, the results indicate slight gender differences in terms of age of household head, size of active household members and levels of education. On age of head of household, many male participants were between 42 and 59 years while many of the female participants were between 39 and 45 years (Figure 3). In terms of size of active household members, male headed households have on average seven active household members than female headed households with about five active households on average (Figure 4). Differences were noted between number of active household members which determine household labor which affect household production. In terms of levels of education, majority of the respondents had primary school education. A slight gender difference is seen at the high school (secondary to postsecondary school) level attained mainly by men than women (Figure 5). Low levels of education affect career choices as such families are limited to small scale farming and other small-scale enterprises. 


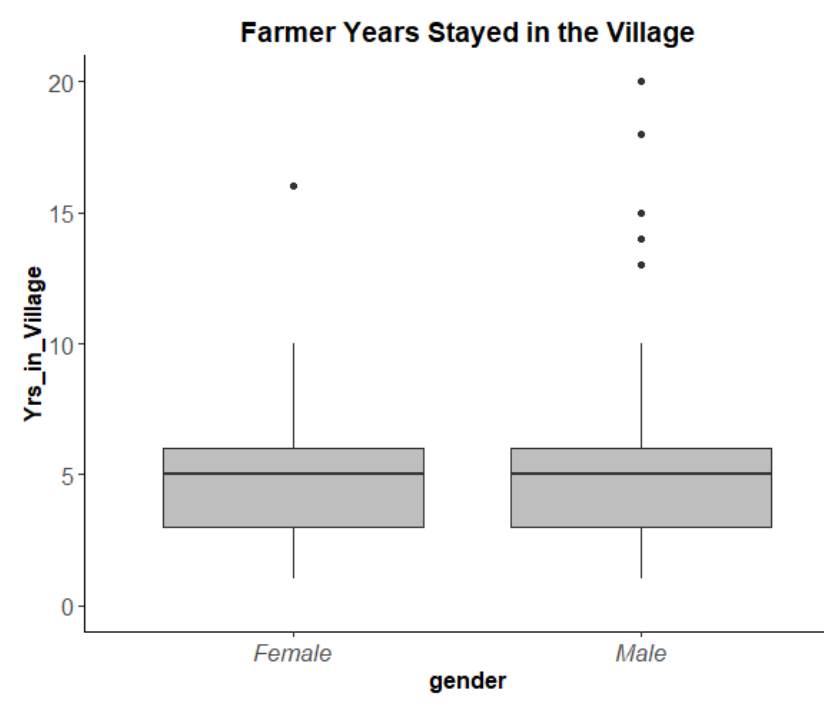

Figure 2: Age of head of household

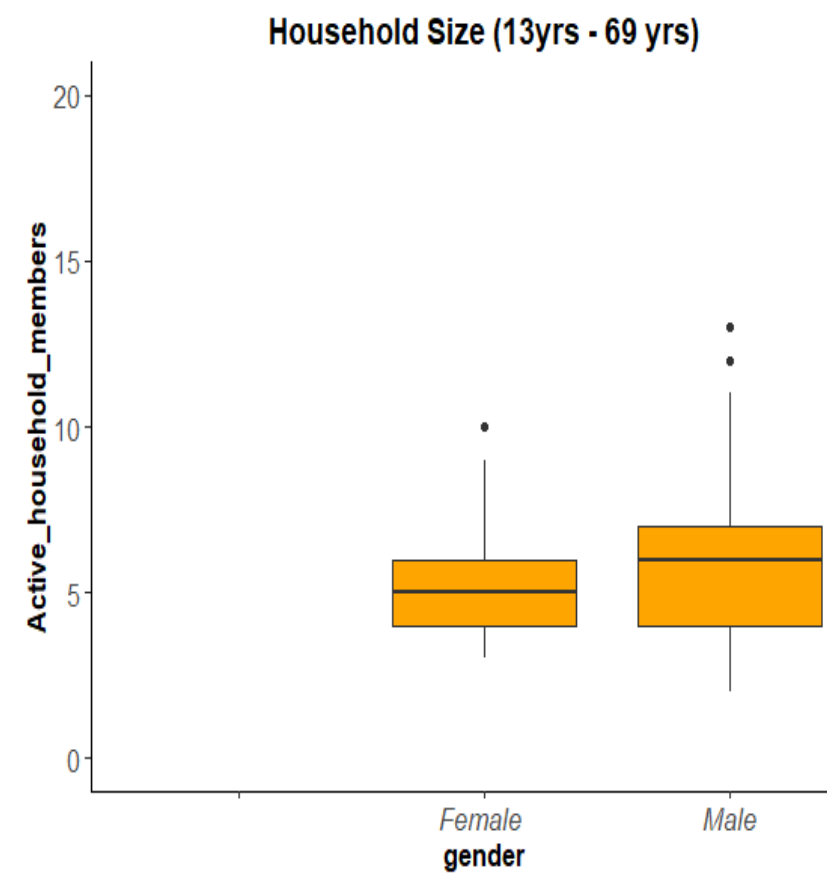

Figure 4: Household size by gender

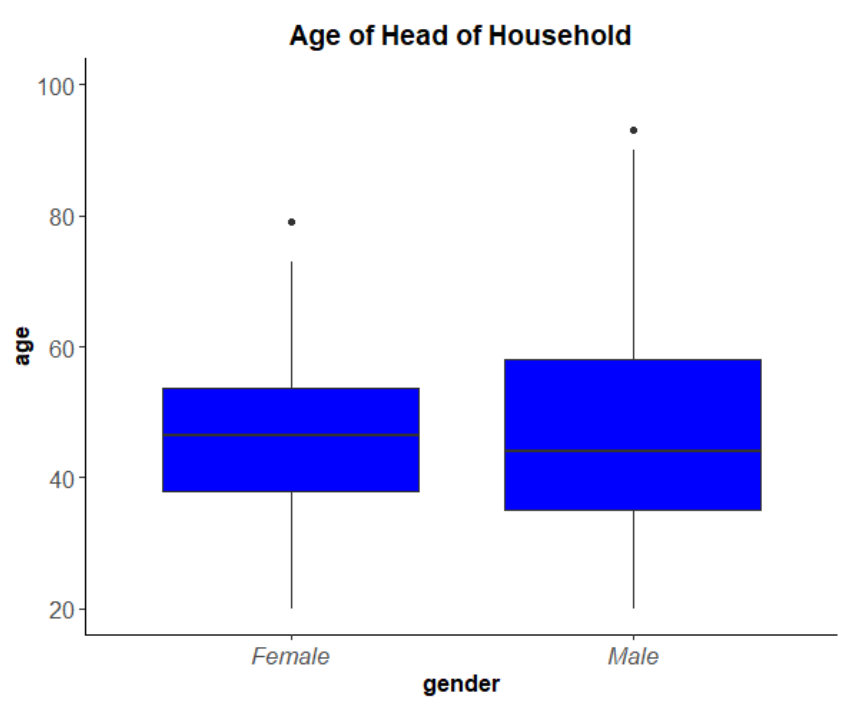

Figure 3: Participant's length of residence in the village

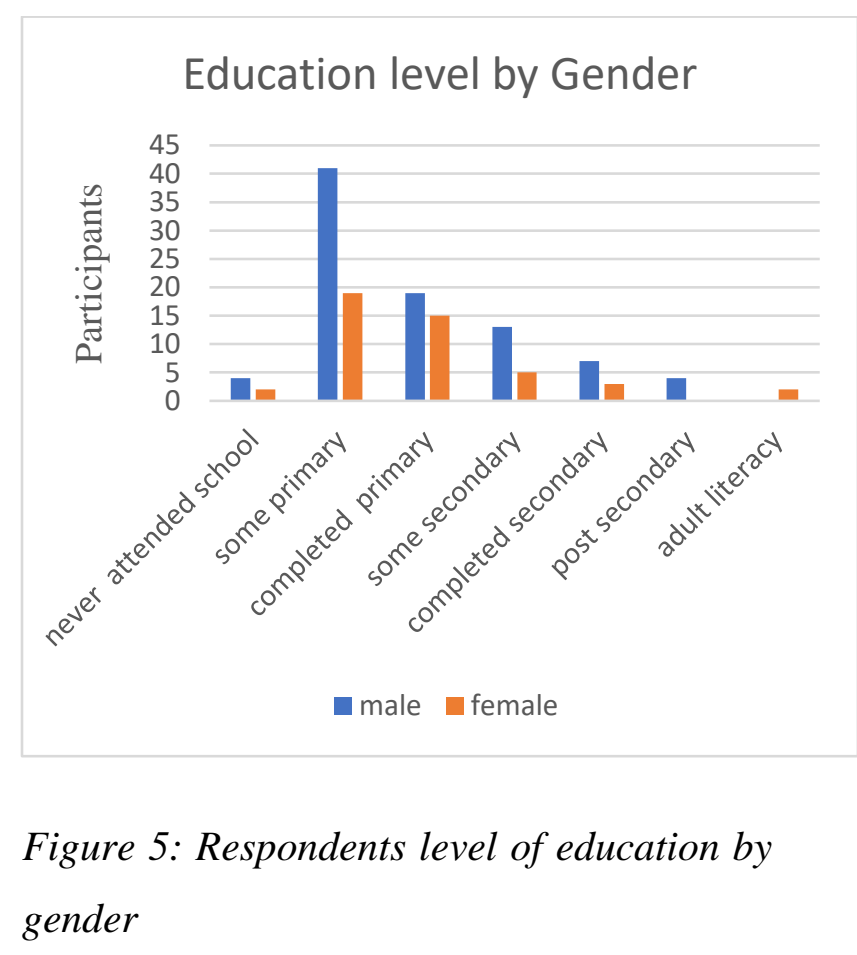


The findings of the household survey show that more than half of the households that participated in the study, ninety-six (71\%) have access to dimba. On the other hand, thirty-nine households (about 29\%) had no access to dimba. In terms of gender, there-are more male headed households, and seventy-six (79\%) with access to dimba compared to twenty (about 21\%) females headed households. On the other hand, about thirteen (33\%) male headed households indicated that they do not own a dimba compared to about twenty-six (67\%) female headed household that indicated that they don't own a dimba. (e.g. Figure 6).

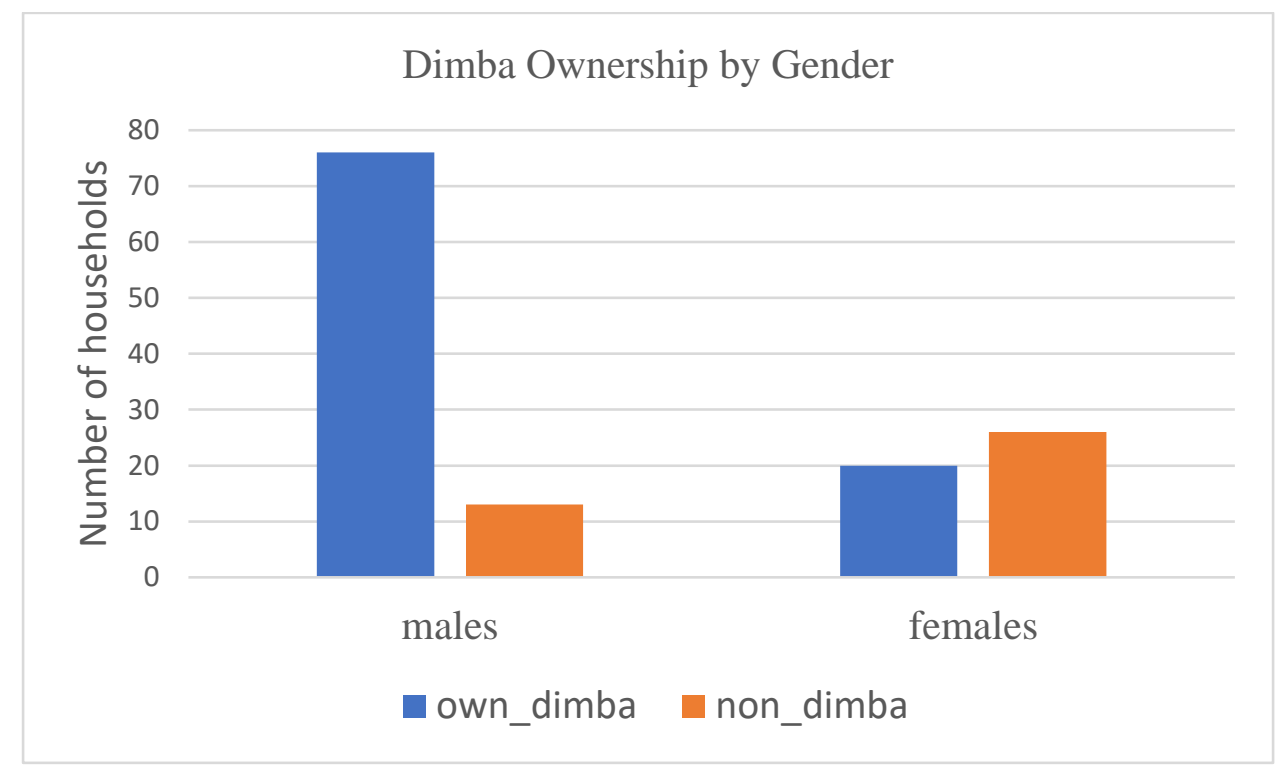

Figure 6: Dimba ownership by gender

Exploratory analysis shows that there is difference in terms of yield, income from agriculture, and the number of months a household have adequate food between households that own dimba and those without dimba (Figures 7,8 \& 10). The difference is more pronounced in terms of income from agriculture. There is also difference in terms of gender. The analysis shows that men have a higher average income than women. This may be due to the observation also made in this study in the following paragraphs that many men on average have larger dimba land than women. In addition, many men tend to sell their dimba crop rather keeping it for their own consumption This observation may explain the results for Figure 8 whereby there is a slight difference in terms of yield between men and women although men own larger dimba. However, there is remarkable difference in terms of yield between women who own a dimba and those without a dimba. On the 
other hand, the analysis shows that there is no difference in terms of crop diversity between men and women as well those who have dimba and those who do not have dimba.

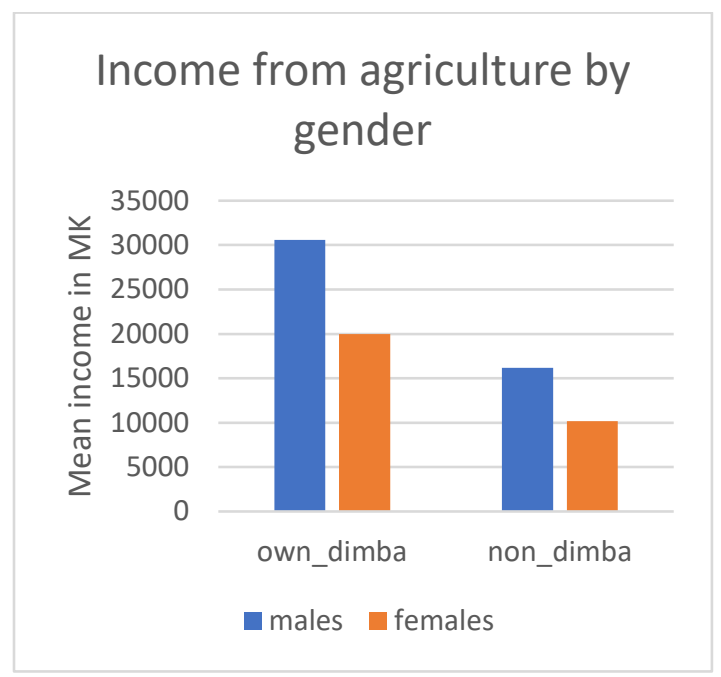

Figure 7: income from agriculture by gender gender

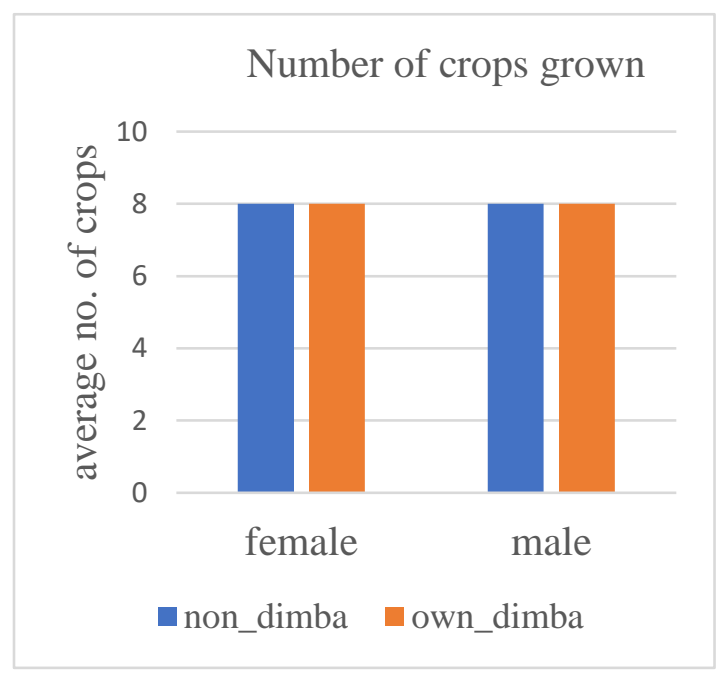

Figure 9: Number of crops grown by gender

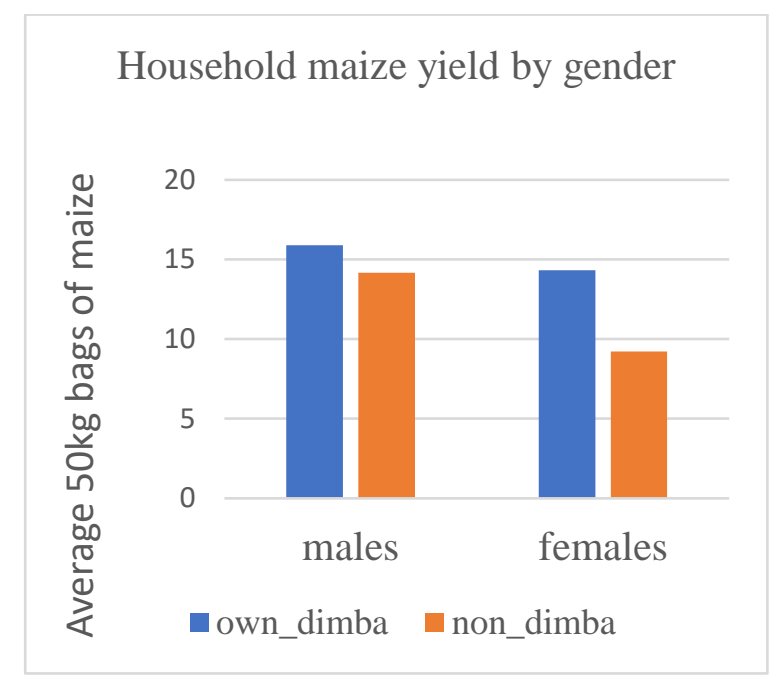

Figure 8: Average maize yield by

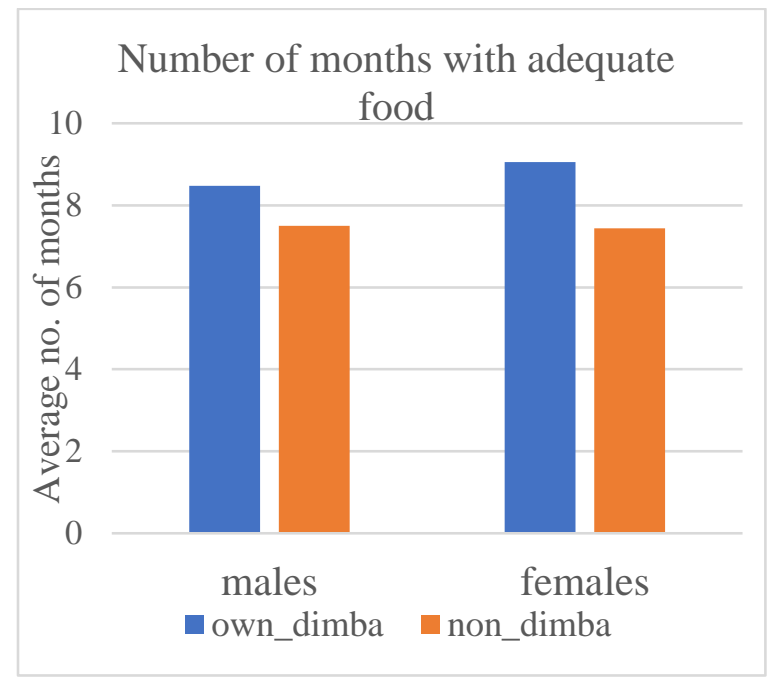

Figure 10: Months with adequate food by gender

\subsubsection{ANOVA, Kruskal-Wallis Test}

Statistical tests were conducted to assess if the difference between household with dimba and those without dimba and between men and women in terms of income from agriculture, maize yield, number of crops grown and number of months with adequate food are statistically significant. To 
test for normality QQ plots were used. All the four variables did not meet normality assumptions as the values are far off from the normal line (e.g. Figures 11-14). A nonparametric analysis of variance (ANOVA), Kruskal-Wallis test was therefore used to assess the difference for all the four variables. Results show that the variations between the farmers/households that have access to dimba and their counterparts without access to dimba in terms of level of income from agriculture, are statistically significant while variations in terms of yield and number of months a household has adequate food are not statistically significant (e.g. see the detailed Kruskal-Wallis tests in Table 1)

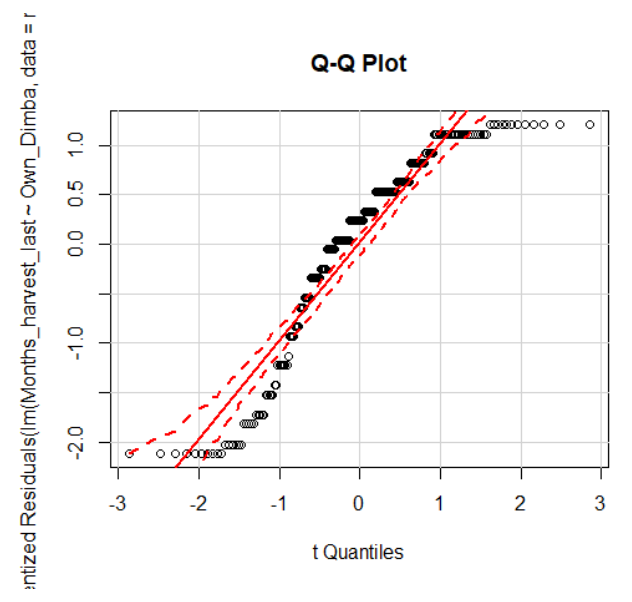

Figure 11:QQ plot for months harvests last

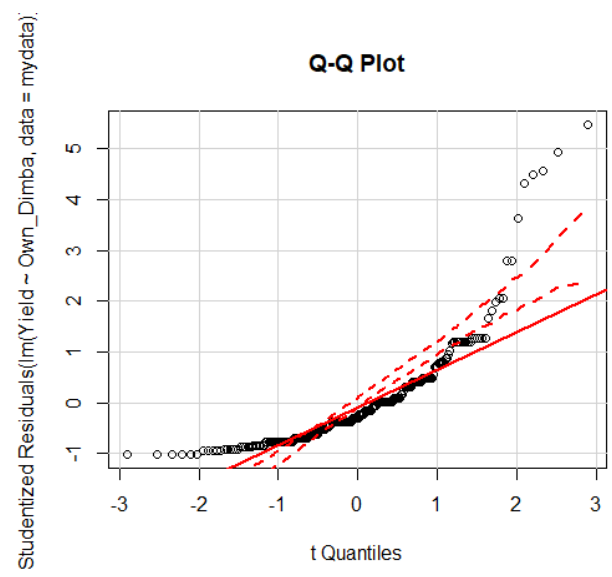

Figure 13: QQ plot for yield

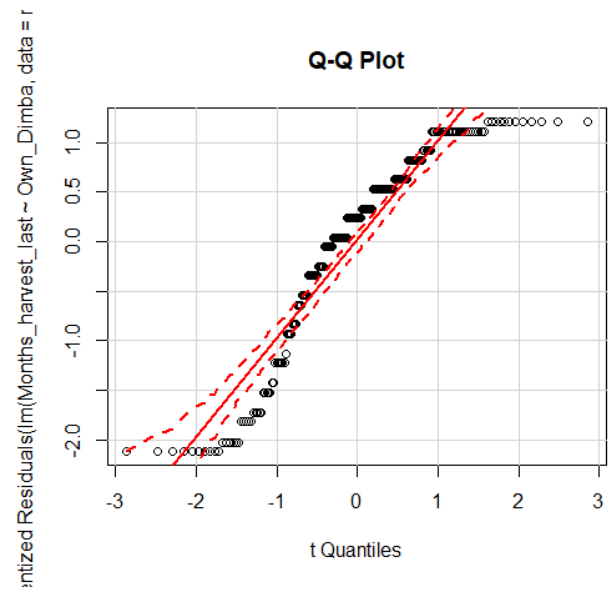

Figure 12: QQ plot income from agriculture

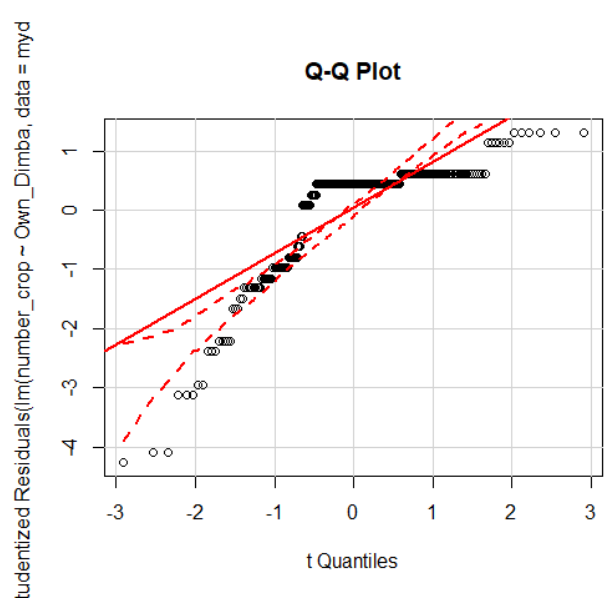

Figure 14: QQ plot for number of crops grown 
However, the number of crops a household grow between farmers that have access to dimba and households without dimba, shows no statistically significant difference.

Table 1: One-way ANOVA test output

\begin{tabular}{|l|l|l|}
\hline Variable & Chi-Squared & P-Value \\
\hline Yield (Maize) & 0.38 & 0.53 \\
\hline Income from agriculture & 3.27 & 0.01 \\
\hline Months with adequate food & 1.48 & 0.22 \\
\hline Number of crops grown & 0.03 & 0.86 \\
\hline
\end{tabular}

A two-way (2-factor) ANOVA which included gender and access to dimba was conducted to further investigate whether or not access to dimba or gender have effect on agriculture income, number of months a household has adequate food, yield and the number of crops a household grow. Two main effects (gender and access to dimba) as well as an interaction effect were analyzed. The two-way ANOVA also showed that access to dimba had an impact on a household's income from agriculture i.e. farmers or households with dimba had on average more income from agriculture compared to their counterparts without dimba, with a p-value of 0.02 . The two-way ANOVA also showed a significant impact of gender on the number of months a household has adequate food with a p-value of 0.04 . The analysis however revealed that the interaction effect of gender and access to dimba were not statistically significant. (e.g. see detailed two-way ANOVA tests outputs below). This can be attributed to small sample size of females with dimba.

Table 2: Two-way ANOVA test output for Number of Crops grown

\begin{tabular}{|l|l|l|l|l|l|}
\hline & Df & Sum Sq & Mean Sq & F value & $\operatorname{Pr}(>\mathbf{F})$ \\
\hline Gender & 1 & 0.3 & 0.27 & 0.04 & 0.85 \\
\hline Own_Dimba & 1 & 0.0 & 0.02 & 0.00 & 0.94 \\
\hline Gender:Own_Dimba & 1 & 5.9 & 5.87 & 0.83 & 0.36 \\
\hline
\end{tabular}


Table 3: Two-way ANOVA test output for Income from Agriculture

\begin{tabular}{|l|l|l|l|l|l|}
\hline & Df & Sum Sq & Mean Sq & F value & $\operatorname{Pr}(>$ F $)$ \\
\hline Gender & 1 & $1.935 \mathrm{e}+09$ & $1.935 \mathrm{e}+09$ & 2.09 & 0.15 \\
\hline Own_Dimba & 1 & $4.793 \mathrm{e}+09$ & $4.793 \mathrm{e}+09$ & 5.18 & 0.02 \\
\hline Gender:Own_Dimba & 1 & $3.235 \mathrm{e}+06$ & $3.235 \mathrm{e}+06$ & 0.00 & 0.95 \\
\hline
\end{tabular}

Table 4: Two-way ANOVA test output for Months with Adequate Food

\begin{tabular}{|l|l|l|l|l|l|}
\hline & Df & Sum Sq & Mean Sq & F value & $\operatorname{Pr}(>$ F) \\
\hline Gender & 1 & 48.4 & 48.36 & 4.15 & 0.04 \\
\hline Own_Dimba & 1 & 7.1 & 7.11 & 0.61 & 0.44 \\
\hline Gender:Own_Dimba & 1 & 1.4 & 0.12 & 0.83 & 0.73 \\
\hline
\end{tabular}

Table 5: Two-way ANOVA test output for Yield-Maize

\begin{tabular}{|l|l|l|l|l|l|}
\hline & Df & Sum Sq & Mean Sq & F value & $\operatorname{Pr}(>$ F) \\
\hline Gender & 1 & 525 & 524.7 & 1.41 & 0.24 \\
\hline Own_Dimba & 1 & 418 & 418.4 & 1.13 & 0.29 \\
\hline Gender:Own_Dimba & 1 & 846 & 845.9 & 2.27 & 0.13 \\
\hline
\end{tabular}

5.2 The role of dimba cultivation in food security and livelihoods adaptation to climate and economic changes

In this section, I present the findings that address the question of contribution of wetland gardens to household food security and its role in supporting rural livelihoods adapt to climate and economic changes.

\subsubsection{Contribution of Dimba to household food security and income}

Participants reported that crops grown in dimba contribute to household food security and income. They explained that though dimba crops are mainly grown for subsistence, they usually produce surplus which they sell for income. Participants explained that smallholder farmers who have large dimba and who afford to buy inputs such as fertilizers and seeds make a considering income from 
growing wetland garden crops such as Irish potatoes, early maturing varieties of maize, sweet potatoes, vegetables, and masimbi (yams). Farmers further explained that though irish potatoes are more input intensive they fetch more income than any other wetland garden crop they grow. They reported that a person with a large dimba and enough fertilizer can get as much as about MK400,000.00 (about \$500) from selling irish potatoes from the dimba

Further, they reported that second production from dimba usually coincides with the lean season (November - February). Farmers reported to get more income from second dimba production as crops tend to fetch very good price during lean season. Farmers explained that income from second dimba production help them with household food security in the lean season. They are able to buy maize if the they did not have enough or if they did not grow in the dimba. Farmers also explained that dimba produce also help to safeguard the little income that households may have as they do not spend money to buy vegetables, sweet potatoes, yams and other crop produce at the market which they already have in their gardens. Thus, participants reported out that farmers with dimba are able to manage food shortage and income problems. Without dimba, participants said, it is a difficult for them to find food and income all year round. Participants also said that dimba acts as a buffer against reduced yield in the upland production. Those who do not have dimba reported that they spend a lot of money to buy food to beef up reduced yield in the upland fields. Many households however reported that they do not afford to buy food from the market.

\subsubsection{Coping and adaptation strategies}

In order to understand how dimba helps households cope with or adapt to climate and economic change, the author asked a series of questions through household survey to generate a list of coping/adaptation strategies. Results show that there is no remarkable difference with regard to strategies employed by men and women. The study also found that strategies employed by smallholder farmers to cope with or adapt to climate and economic shocks are remarkably few (McCusker, B. 2016). Most common coping/adaptation strategies included dimba, business, ganyu labor and Village Savings and Loans (VSL). Through FGDs participants explained that dimba is the main strategy that most households in the study area use to cope with and or adapt to climate and economic shocks. Participants explained that dimba cultivation helps them to find food and money even when the rains are poor. A woman in Kavuzi pointed out "dimba is our main source of livelihood now a days when there is drought. Without dimba we may suffer a lot" (Ruth Chirwa, 
26 May 2018). With dimba, farmers reported, they are able to produce twice or more in a year. When production has failed in the upland gardens. Participants explained that unlike in the past when they used to have good rains almost all through the rainy season, recently the rains have been unpredictable. Often rains start late and end early and are associated with dry spells. Participants explained that dimba has thus become buffer against the unpredictable weather patterns.

While ganyu labor and business are also employed as coping/adaptation strategies they are not as helpful or effective in this area. Participants explained that in the course of doing ganyu they lose time to work in their dimbas. As a result, they either plant late or are not able to take good care of as their own gardens since much time is spent doing ganyu. In addition, ganyu is not easy to find because very few people can afford to hire ganyu. Since the main source of ganyu in the area is cultivation, ganyu becomes very scarce when the rains are poor as many do not want to spend a lot to cultivate. Sometimes they get their payments very late. Participants had similar views about doing business, they explained they do not have sufficient money to do business. Small scale businesses they do selling mandazi, banana cannot help them meet their household needs. Other strategies such as fishing were only found in Sanga which is along Lake Malawi. Some women also reported to that they engage in village saving and association, a form of micro-credit that empowers households, particularly women, to be more financially self-sufficient; and helps households become more resilient to climate change through use of and access to a broader set of livelihood strategies i.e. diversify into micro-businesses. This strategy also is only employed by few women who can afford to make some savings.

Participants further pointed out that even though they rely on dimba as a strategy to cope with or adapt to weather perturbation, climate change is bringing climatic conditions beyond what local farmers have experienced in the past. They explained in the past water was never scarce as rivers/streams would flow all year round. But recently, they said, with poor rains the sources of water for dimba irrigation such as streams/rivers or shallow wells dry up. To irrigate crops when the water sources have dried up due to poor rains men have dig deep wells to find water. Participants further explained that digging deep wells and irrigating crops from deep wells is painstaking and time consuming. Female participants explained that due to water scarcity they walk long distances in search of water. This causes them to have less time to work on their dimbas as they spend much time walking long distance in search of water for household use. Women also 
reported that walking long distances to fetch water exposes them to dangers such being raped or attacked by wild animals e.g snakes. Some women further explained that water scarcity also threatens their marriages. They explained that some husbands take the two hours length to fetch water as a lie, they think we go to meet other men". Women explained that this negatively affects/erodes trust and cause conflicts thereby affecting productivity i.e. their working together in dimba as a family.

\subsection{Ownership, access and use of dimba: gender and other social markers governing wetland gardens.}

In this section, I present the findings that address the question of ownership, access and use of dimba, how gender in relation to other social markers, such as widowhood and divorce governs ownership, access and use of wetland gardens. Through qualitative research I conducted 18 FGDs with groups of women separate from men. This was done to establish gendered dimba ownership and livelihood patterns

\subsubsection{Ownership and use of wetland gardens}

Almost all the land in the study area is under customary tenure. Customary tenure does not necessarily grant land ownership but rather long-term rights of use through communal decisionmaking authorities i.e. chiefs. In this study, therefore, land ownership loosely means long-term right of use. As a patrilocal system, like upland fields, the study found that wetland gardens in the study area are owned by men. Women only get to access or use the wetland gardens through their husbands. Participants reported that ownership of wetland gardens are inherited by sons. People without wetland gardens get access to use the gardens through renting. However, participants reported that it is very expensive renting a wetland garden. Women also explained that when one rents a wetland garden and seem to be producing more than the owner, the owners tend to feel jealousy and stop him or her from using their garden.

The plight of women in ownership and accessing wetland gardens is further compounded by other social markers such as marital status i.e. widowhood, and divorce. Participants explained that most women lose access to wetland gardens when the husband dies. This happens most especially when the widow moves out of the husbands place to somewhere or to her parent's home. Women participants further pointed out that even widows who remain at their marital home, their access to wetland gardens after the death of their husbands is not without challenges. Some clan members 
sharing boundary with the widow tend to take advantage of her widowhood and push their boundary into the widow's garden, particularly when the widow has no male children or if they are too young to defend her. Participants explained that divorced women lose their access to the wetland garden. When they go to their parents' home, accessing wetland garden is at the mercy of their brothers who may/may not decide to share with them the wetland garden.

The difference between men and women with regard to access to wetland garden is also manifested in size of the wetland gardens. Dimba plots are of varying sizes, with some big and some very small. It was reported that on average the smallest size is about $1 / 2$ acre and the biggest size is about 3 acres. Some groups reported the smallest to be $1 / 4$ acre and the biggest as 5 acres. In general, more women reported to have small size wetland gardens dimba than men (see figure below).

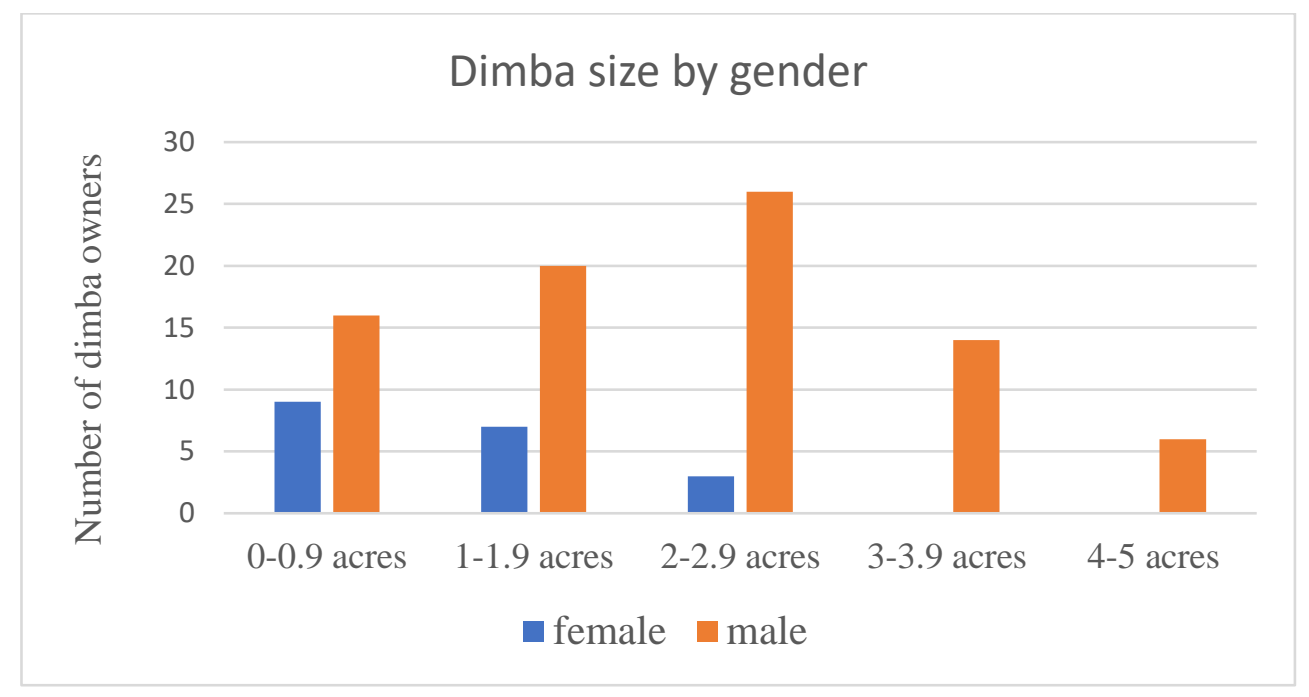

Figure 15: Dimba size by gender

The study also found that sizes of dimba were reported to have decreased due to population growth. Compared to the past, increasing population has led to subdividing of the wetland gardens among increasing household members. Dimba plot size was also reported to be affected by rainfall - too low or too high rainfall. Participants reported that very low rains make streams water levels to be very low and dimba areas far from the streams/rivers to dry up quickly as such with scarce water such places are not used to plant dimba crops. They also reported that heavy rains tend to erode the river banks hence widening the stream sizes and reducing dimba sizes. 


\subsubsection{Control and use of income from dimba agriculture}

The study also uncovered differences with regards to control and use of income from dimba between men and women. Women participants reported that husbands tend to dictate on how the money should be used and usually take a bigger share and use it for their own personal needs like buying airtime to call their secret girlfriends or spend it on beer. Women participants further lamented that some cruel husbands demand to know how much their wives have profited from dimba sells and be given bigger share even if they themselves did not help or were not involved in the dimba cultivation. When women do not disclose, they get beaten or sometimes the husbands steal the money if it is not hidden very far.

Women claimed that they use the money from dimba to meet household needs. They explained that children and everyone at home looks to them for food. So, as they are the ones who take care of the home, they make sure that income they get from dimba help them with households needs. In the words of a woman from Chipimbininga,

"we use the money we find from dimba wisely so that our children do not go hungry and start looking for food from the neighbors. When that happens, it brings shame to the mother. So, we make sure children have food at home".

Women further claimed that they manage the dimba crops properly. They reported that they always wait for dimba crops to mature before they sell or start using for food. However, they said the problem is with their husbands especially those who drink beers, start selling the crops before the crops have matured simply because they want money for beer.

Men participants however defended themselves, they explained that though some men indeed use the income from dimba for beer, many of them use the income responsibly to support their families. Some men also accused women of using income from dimba for personal needs such as doing their hair and buying clothes to compete with fellow women.

\subsection{Proximity to stream banks and ownership of wetland gardens}

In this section, I present the findings that address the question of geographic factors of proximity to river/stream affect ownership or access to wetland gardens. Through OSM generated stream data and household GPS coordinates were used to explore relationship between proximity to stream and dimba ownership. After mapping the streams in OSM, stream data was exported to 
ArcGIS for spatial analysis. To determine if proximity of households to a stream affects dimba ownership, Euclidean buffer analysis was conducted. Euclidean buffers measure distance in a two-dimensional Cartesian plane. Euclidean buffer analysis was used because it works well analyzing distances around features which are concentrated in a relatively small area (ArcGIS 10.5 Help Documentation). Buffer analysis of 500m was done for Mpamba and Sanga only. For Kavuzi, it was difficult to generate stream data on OSM due to forests. $500 \mathrm{~m}$ was used because it was the shortest distance that was travelled to the wetland gardens.

\subsubsection{Buffer analysis}

Buffer analysis results (Figure 16) show proximity to a stream does not influence dimba ownership. The results show no clear pattern to indicate households that own wetland gardens are close to a river/stream or that households without wetland gardens are far from a river/ stream. For instance, out of the seventy-one households that own dimba in Mpamba and Sanga, thirty-six were within the distance of $500 \mathrm{~m}$ from the stream while thirty-five households that own dimba are outside the $500 \mathrm{~m}$ buffer. On the other hand, only nine households without dimba are within the $500 \mathrm{~m}$ buffer. A large portion of households without dimba, about twenty, are outside the $500 \mathrm{~m}$ buffer. 


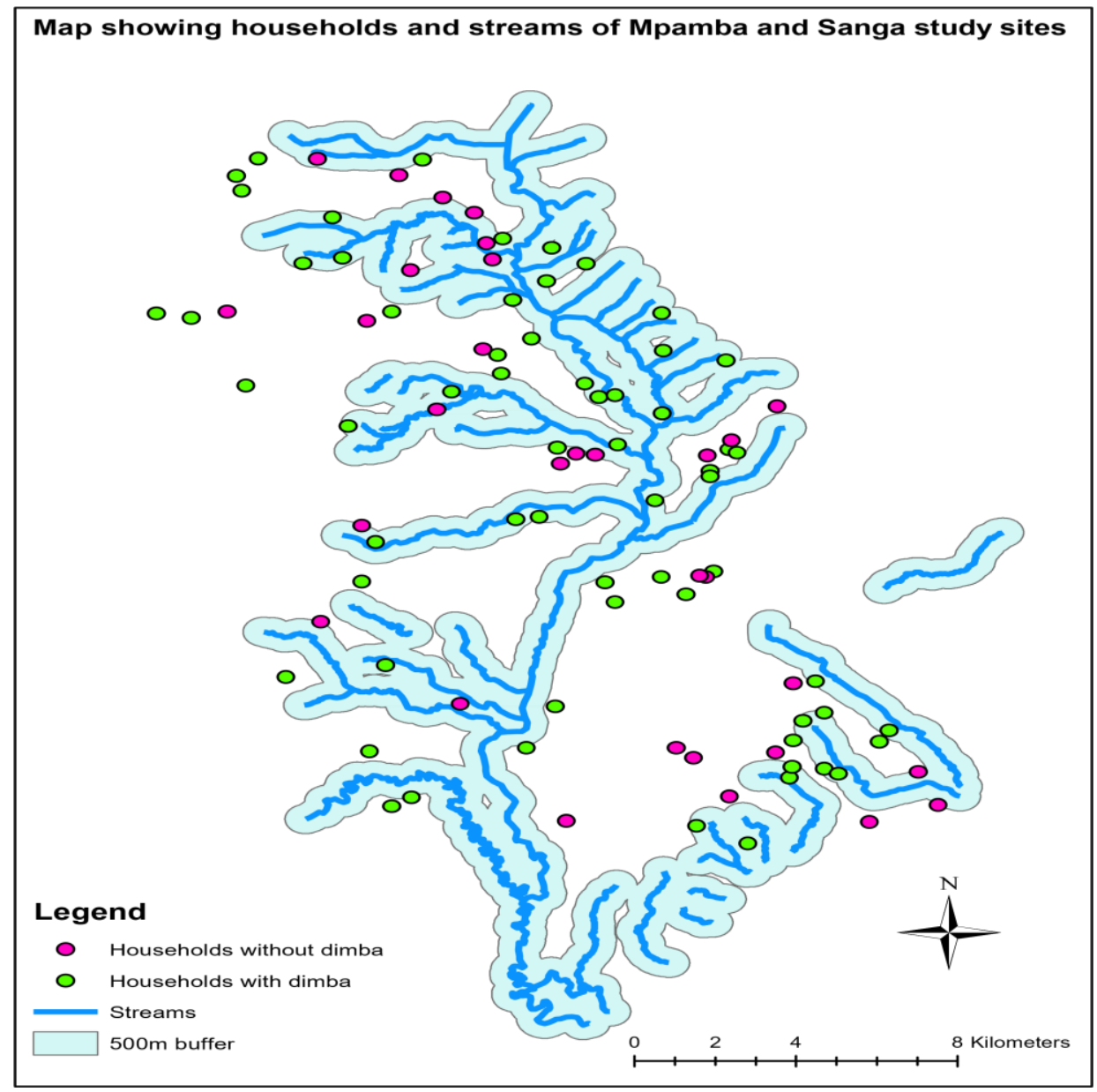

Figure 16: Map showing streams and households

\subsection{Role of dimba cultivation in food security and livelihoods adaptation to climate and economic changes}

In this section, I present the findings that address the question of contribution of wetland gardens to household food security and its role in supporting rural livelihoods adapt to climate and economic changes.

\subsection{Extent and change in the wetland cultivation}

The aim of the land use land cover analysis was to visualize and quantify dimba cultivation growth in the study area. Analysis was carried on a subset of $1393 \mathrm{~km}^{2}$. No image pre-processing i.e. geometric co-registration and spectral radiometric normalization was conducted because both images had same projection system UTM Zone 36 (WGS 84) and the change detection method (post classification) employed in this project does not require radiometric normalization 
(Warner2008). The only pre-processing conducted was sub-setting the study area from the original images using ERDAS IMAGINE 2018 to an area of $1393 \mathrm{~km}^{2}$

\subsubsection{Classification}

Using unsupervised classification, the multi-date images were separately classified into 36 clusters. The resulting clusters were examined to determine the land use/ covers which corresponded to each cluster for both images. The clusters which were spectrally similar in both images were recoded into similar land use/cover class. Each image was recoded into 5 classes: water, dimba land, vegetation, dambo/marshy land and built up area as shown in Figures 17 and 18 below. Some classes such as vegetation and built up area had sub classes. Vegetation on one hand, included forests, shrubs, grasses, plantations i.e. rubber and tea. On the other hand, built-up area included villages, roads, huts, cleared land and sandy soil banks.

The low resolution of the images made separation of some land covers i.e. crops and grass/marshy land difficult due to spectral similarity. Separation of these confusing classes were complemented by Google Earth which was linked to ERDAS IMAGINE such that the two worked simultaneously. For instance, zooming in and out an image in ERDAS IMAGINE, simultaneously zooms in and out Google earth image. So confusing classes were separated by zooming in a land use class on an image in ERDAS IMAGINE which simultaneously zoomed it in Google earth making it clearly visible. Then, the land use/cover was assigned as dimba or vegetation depending on how it appears on Google earth. 


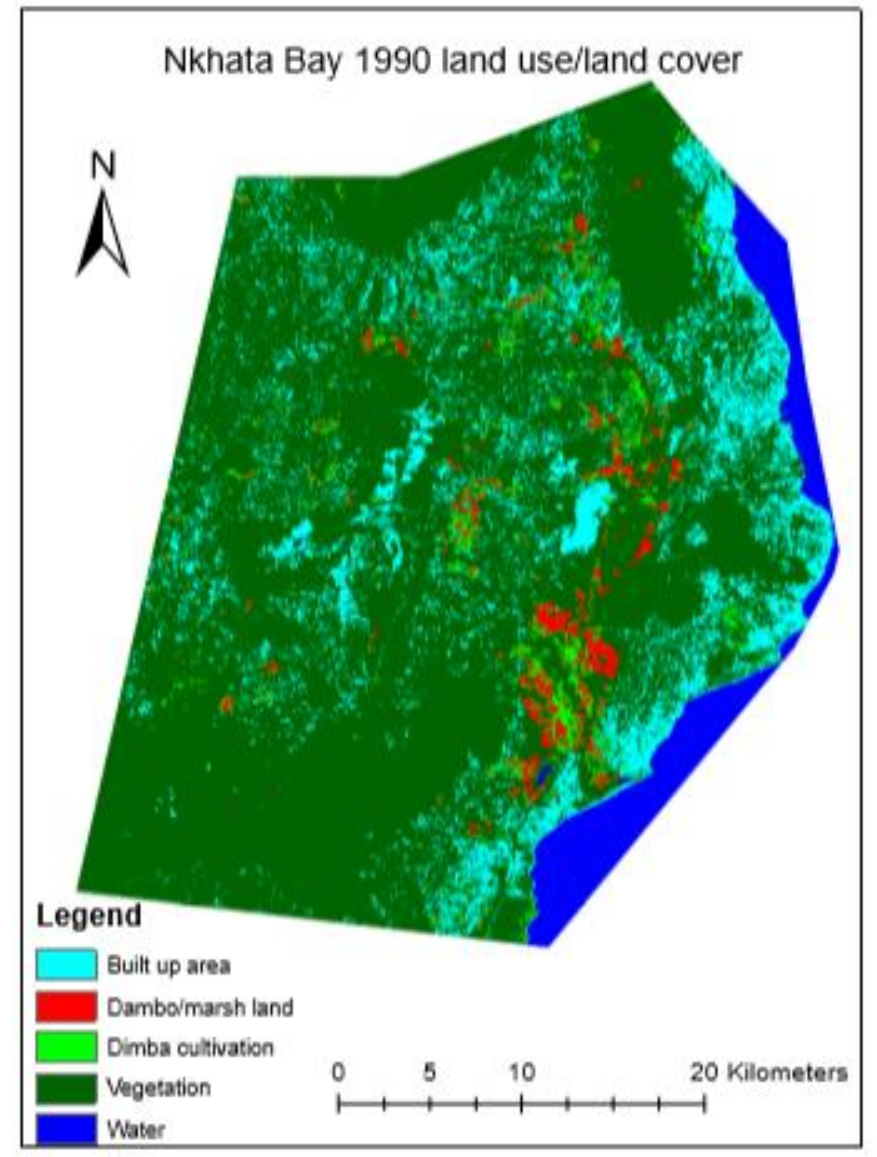

Figure 17 land use-land cover map for 1990

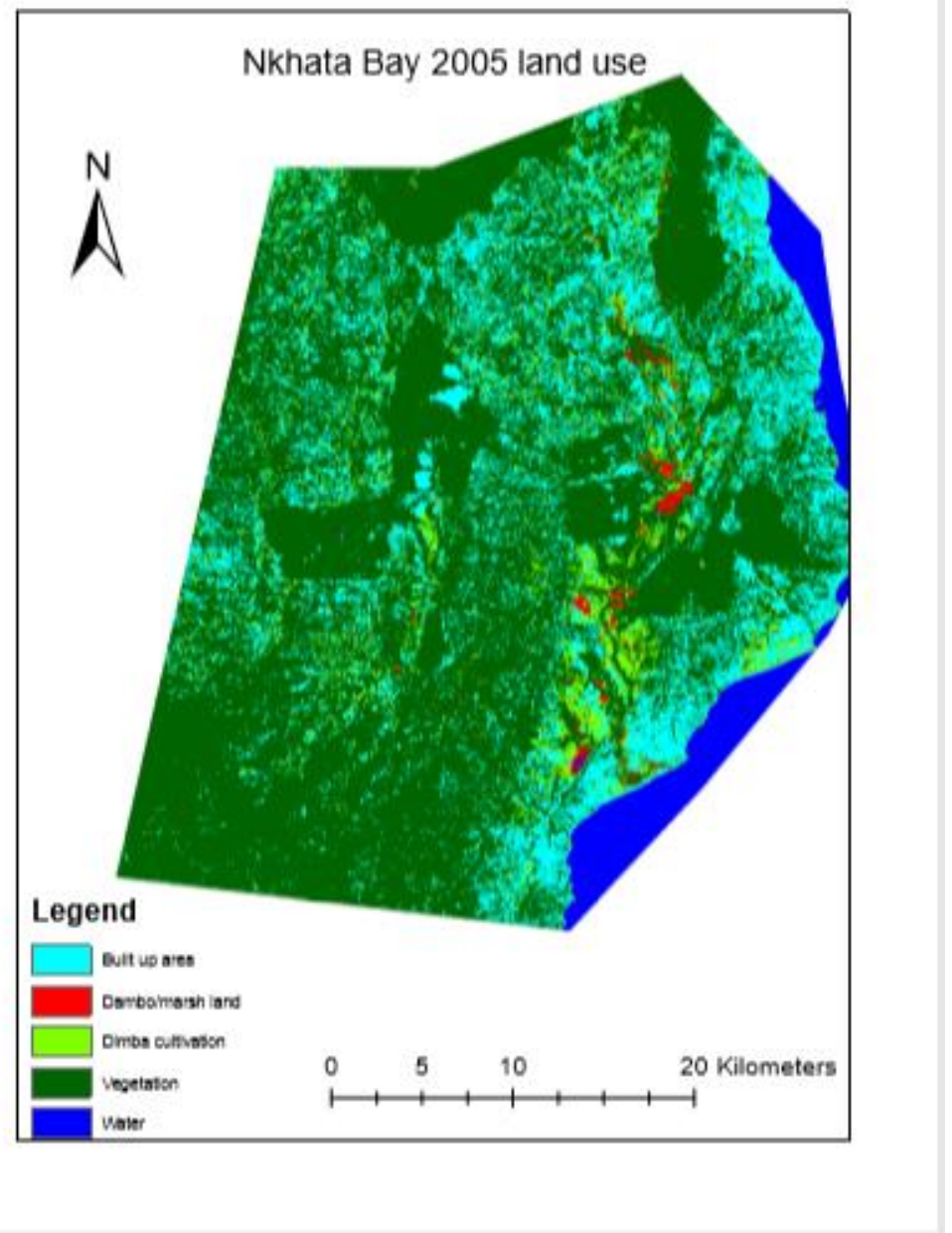

Figure 18 land use-land cover map for 2005 


\section{Land Use-Land Cover Statistics for 1990 and 2005}

Table 6 below shows the static land use/cover classes' area coverage in hectares and percentages. Summarily, the study indicates that between 1990 and 2005 dimba cultivation increased. In 1990, dimba cultivation covered about 3685.41ha (2.6\%) while in 2005 it covered 8023ha (5.8\%). The other class which increased was built up area. While water, vegetation and dambo/ marshy land decreased.

Table 6: Static statistics of land use/cover classes, 1990 and 2005

\begin{tabular}{|l|l|l|l|l|}
\hline \multicolumn{1}{|c|}{ LULC class } & \multicolumn{1}{|c|}{ Area (ha)1990 } & Percent 1990 & Area (ha) 2005 & Percent 1990 \\
\hline Water & 7849.35 & 5.63 & 7388.1 & 5.31 \\
\hline $\begin{array}{l}\text { Dimba } \\
\text { cultivation }\end{array}$ & 3685.41 & 2.64 & 8023 & 5.77 \\
\hline Vegetation & 105223 & 75.42 & 94193.7 & 67.73 \\
\hline Built up area & 19680.12 & 14.11 & 28506.42 & 20.43 \\
\hline $\begin{array}{l}\text { Dambo/marshy } \\
\text { land }\end{array}$ & 3075.48 & 2.2 & 967.5 & 0.70 \\
\hline
\end{tabular}

Visualizing the changes in all the classes between 1990 and 2005 Figure 19 shows there was a remarkable increase from 1990 to 2005 in the built-up area followed by dimba cultivation. On the other hand, there was remarkable decrease in vegetation. 


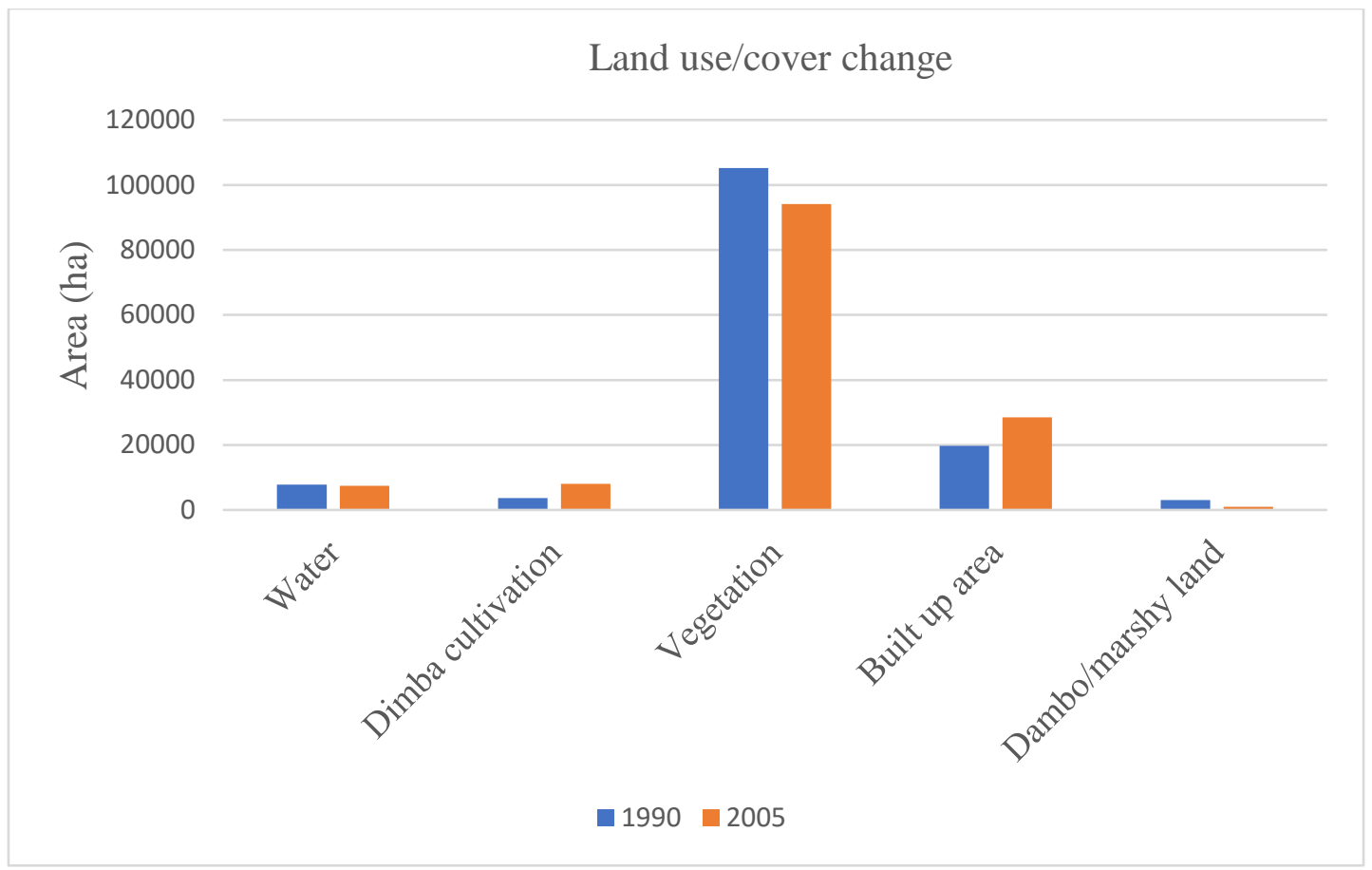

Figure 19: Summary of 1990 - 2005 land use/cover change

\subsubsection{Change detection - post classification analysis}

In order to visualize and quantify dimba cultivation growth in the study area, post-classification analysis was carried out by overlying the 1990 and 2005 images. Both images had the same number of classes and the same DN assignments for each class. Change classes were re-coded from the original thirty-six to four classes: dimba increase, dimba unchanged, no change and non dimba change. These land cover classes were designed to highlight dimba cultivation growth. Figure 20 below shows the pattern of land use/cover change between 1990 and 2005 in the study area. 


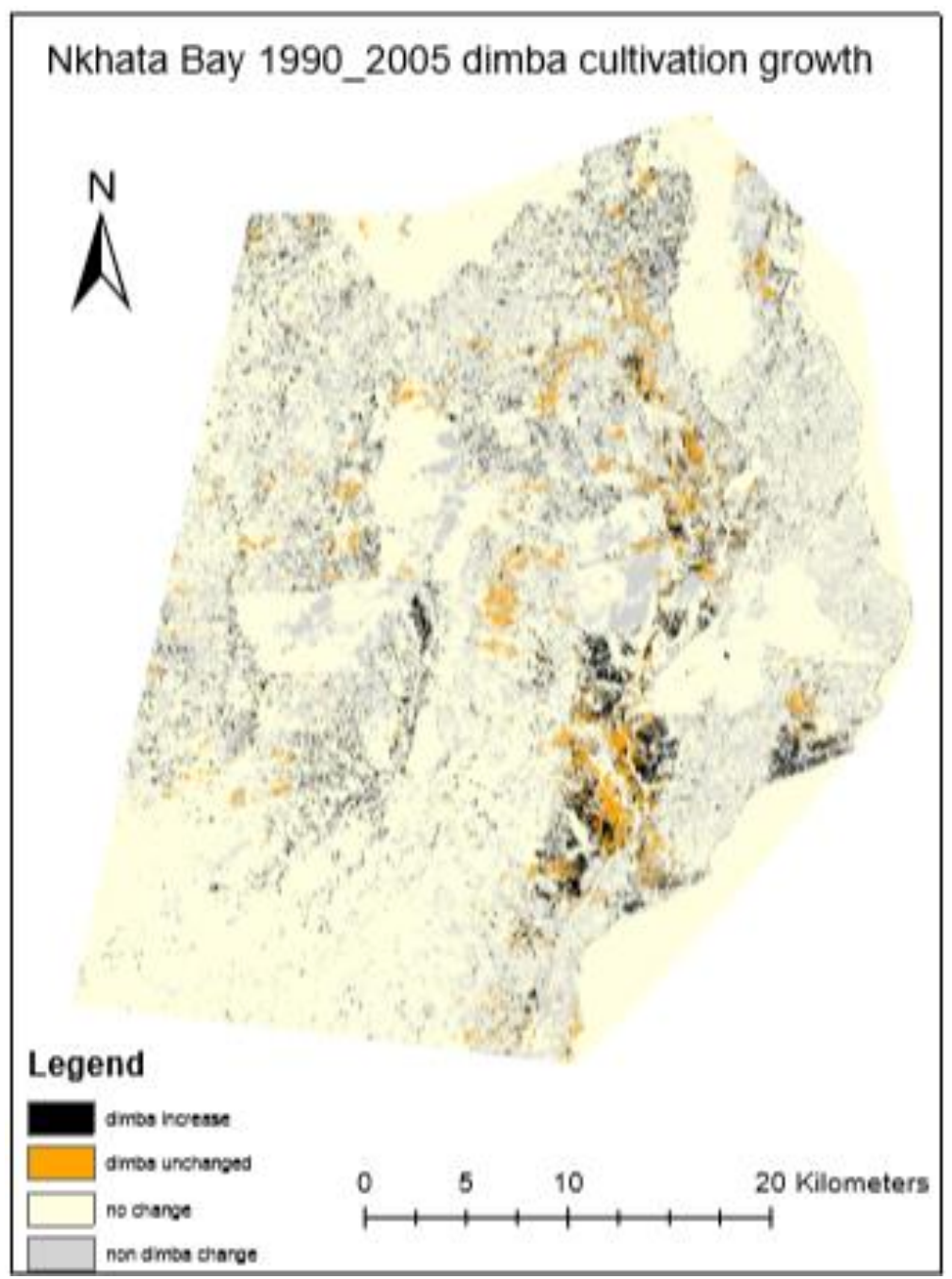

Figure 20: Change detection map

\subsubsection{Accuracy assessment}

To properly perform accuracy assessment, one of the requirements is reference data with date of acquisition close to the acquisition date of the older images. However, to get such data is a big challenge. As such, original Landsat images, maps, photos among other data are used as reference data (Lung and Schaab 2006). In this study, the 2007 Google earth image was used as reference data for the accuracy assessment of the 1990-2005 change detection map in ERDAS IMAGINE. Using stratified random sampling technique, 250 were loaded into post classified image. These points were visually compared to their location on Google earth. Knowledge of the study area helped to improve the accuracy. Accuracy reports, error matrices and Kappa statistics were produced indicating an overall accuracy of $88.4 \%$ (Tables 7 and 8 ) 
Table 7: Error Matrix for 1990 - 2005 change detection map

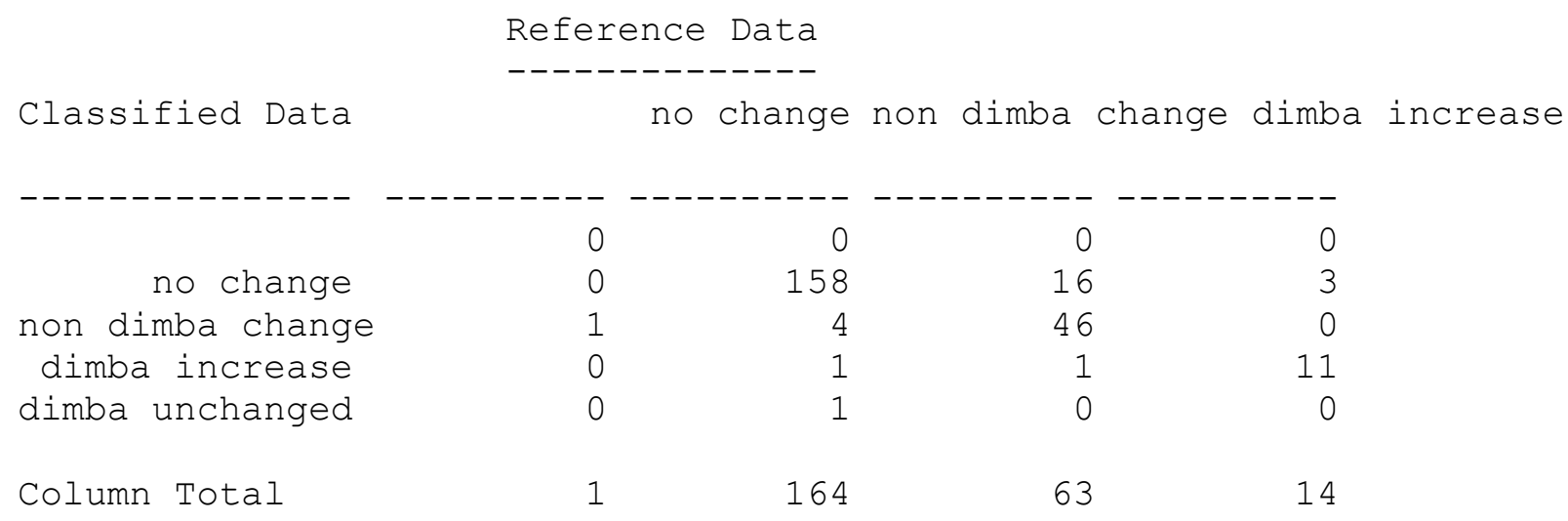

Table 8: Accuracy totals for 1990 - 2005 change detection map

\begin{tabular}{|c|c|c|c|c|c|}
\hline $\begin{array}{l}\text { Class } \\
\text { Name }\end{array}$ & $\begin{array}{r}\text { Reference } \\
\text { Totals }\end{array}$ & $\begin{array}{c}\text { Classified } \\
\text { Total }\end{array}$ & $\begin{array}{l}\text { Number } \\
\text { Correct }\end{array}$ & $\begin{array}{r}\text { Producers } \\
\text { Accuracy }\end{array}$ & $\begin{array}{l}\text { Users } \\
\text { Accuracy }\end{array}$ \\
\hline--- & 1 & $\begin{array}{r}-- \\
0\end{array}$ & $\begin{array}{c}------ \\
0\end{array}$ & $\begin{array}{r}--------- \\
---\end{array}$ & $\begin{array}{r}----- \\
---\end{array}$ \\
\hline no change & 164 & 179 & 158 & $96.34 \%$ & $88.27 \%$ \\
\hline non dimba change & 63 & 51 & 46 & $73.02 \%$ & $90.20 \%$ \\
\hline dimba increase & 14 & 13 & 11 & $78.57 \%$ & $84.62 \%$ \\
\hline dimba unchanged & 8 & 7 & 6 & $75.00 \%$ & $85.71 \%$ \\
\hline Totals & 250 & 250 & 221 & & \\
\hline
\end{tabular}

\subsection{SUMMARY AND CONCLUSION}

Employing mixed methods approach this study attempted to address the following questions: 1) How does dimba cultivation contribute to food security and livelihoods adaptation to climate change? 2) What governs ownership and use of dimbas? The analysis intended to appreciate if dimba contributes to household's income and food security; how gender and distance influence access to dimba; the role of dimba as adaptation to poor rains, and the extent of dimba land change between 1990 and 2005 .

The study has revealed through exploratory analysis and statistical test i.e. ANOVA that there is significant difference in terms of food security (measured as number of months a household has adequate food), agricultural income, and yield between households with dimba and those without 
dimba. Thus, dimba contribute to household's food security and income in Nkhata Bay. This is mainly because dimba enables households to harvest more than once a year. With sufficient input a household can get as much as $\$ 500$ from dimba crops such as Irish potatoes. Most importantly the second dimba harvest coincide with lean season (November - February) and thus it serves as cushion against hunger. Second crops also fetch high market price thereby boosting household income. The findings of this study thus strongly support the assertion that dimbas play a vital role in rural livelihood security and resilience. Further, our study corroborates with a similar research conducted in Simlemba, central Malawi, Cyabayanga in Rwanda, and in Tanzania which indicated that wetland cultivation accounts for more than $40 \%$ of domestically consumed food and generates about more $50 \%$ of household cash income (Msusa 2011, Mahenya 2008, Nabahungu and Visser 2011).

Although dimba cultivation plays a vital role in household food security and income the study had mixed results. FGDs revealed that ownership of dimba in Nkhata Bay is affected by gender while statistical tests (two-way ANOVA) revealed that the interaction effect of gender and access to dimba was not statistically significant. This can be attributed to small sample size of females with dimba.

Consistent with observations by Simon (2014); Kambewa (2005); and Helliker \& Murisa (2011), as a patrilocal system, in Nkhata Bay wetland gardens are owned by men, women only get access through their husbands. Although women are at the center of wetland cultivation, they have less control over wetlands gardens. The difficulty of women in accessing wetland gardens is further compounded by widowhood, and divorce. The study has revealed that most women lose access to wetland gardens or face challenges accessing wetland gardens when the husband dies.

Through buffer analysis, the study has shown that dimba ownership is not related to distance to a stream. About $50 \%$ of households that own dimba in the study sites are close to a stream and $50 \%$ are not close to a stream.

Drawing on qualitative analysis the study took a step further to understand the role of dimba in coping with weather shocks. Generating the list of coping strategies, the study found that smallholders farmers in Nkhata Bay have remarkably few coping strategies. Some of the coping/adaptation strategies included dimba cultivation, business, ganyu labor, village loans and 
savings especially among women, and fishing for those along the lake. However, dimba was identified to be the most important and common coping strategies. With unpredictable rainfall, when production fails in the upland-gardens, smallholder farmers rely on dimba as buffer. To echo the arguments raised before, through dimba, smallholder farmers and communities survive long dry seasons and waistband low yield due to poor rains.

Building on qualitative analysis which has indicated that dimba is the most important and common livelihood strategy in the study area, the study employed land use/land cover analysis to explore if land under dimba cultivation has changed. Through post classification change detection, the study has shown that wetland cultivation from 3686 ha in 1990 to 8023 ha in 2005. Such a rapid increase in dimba cultivation can be attributed to emphasis by the government and NGOs on irrigated agriculture as a means to bridge the 1991/92 drought and ensure food security (Saka et al. 1995, Kamthunzi 2000). Arguably increase of dimba cultivation may point out to the hypothesis that smallholder farmers are employing dimba cultivation as an adaptation strategy to climate shocks.

The impacts of this study are manifold. In the first place the research contributes to a growing body of scholarship on gender inequalities in access to land, as well as provide practical insight into the challenges affecting dimba cultivation. At a lower level of thought by putting streams where dimba cultivation takes place on OSM may stimulate the public to critique and contribute to the generation of spatial knowledge about dimba cultivation. This study may also be useful to other

stakeholder such as NGOs, policy makers who may want to know where small holder dimba cultivation takes place.

\subsection{RECOMMENDATIONS}

Based on the results, this section presents recommendations to stakeholders e.g. government, NGOs and farmers. These recommendations mainly are on current problems of dimba access, gendered challenges in dimba production, and challenges facing dimba production in the future given population increase, and climate change.

\subsection{Current problems of dimba access}

Since the study has established that access to wetland gardens is through inheritance and is gendered, it is recommended for the government to ensure females rights to land ownership including dimbas are secured. While it is appreciated that the government is implementing the 
2016 Land Act which empowers every Malawian including women to own land through registration of customary land, the government need to come up with clear measures that will indicate how women's rights to land ownership will be safeguarded since access to land and dimbas is embedded in social ties and power relations (Msusa 2011).

\subsection{Gendered challenges in dimba production}

Currently implementation of the 2016 Land Act is in the pipeline. However, there are some doubts as to whether many people would accept land titling very quickly. Land access through inheritance may still operate for some time. NGOs interested in helping wetland smallholder farmers should therefore take into consideration inheritance land ownership for their projects to be sustainable. In addition, if wetland cultivation projects are to be helpful, they should also aim at empowering women. One way of empowering women in this case would be establishment of schemes because schemes accommodate a lot of people. However, establishment of schemes means devolution of individual user rights to group rights. If farmers persist to operate as individuals/schemes fail, farmers should form groups for purposes of accessing loan from NGOs i.e. micro finance institutions. According to Malunga (2009) many credit organizations require farmers to be in groups because groups are easy to deal with and track for loan repayment.

\subsection{Future challenges of dimba production given population growth and climate change}

According to FAO (1996), local farmers in Malawi perceive droughts as one of the causes of poverty. FAO (1996) further said that increase in food insecurity and poverty as caused by droughts increases the dependency on wetlands. Similarly, population growth increases demand for wetlands for food production. Increased demand for wetlands for cultivation results into unsustainable wetland cultivation which causes drying of streams, soil erosion, runoff among other problems. These problems may lower production in the wetlands. So, to ensure sustainable wetland agriculture, it is recommended for farmers to practice conservation agriculture. According to the Ministry of Agriculture (2005), conservation agriculture helps to improve water infiltration and soil structure, reducing erosion and thus increasing yields. However, the government or NGOs through agricultural extension workers need to civic educate farmers about conservation agriculture. 
In addition, as revealed in this study through FGDs population increase has led to reduced dimba sizes. So, for farmers to continue benefiting from dimba cultivation, as it has been revealed again by the study that wetland cultivation contributes significantly to income and food and that it is a common and major adaptation strategy in the study area, it is recommended for government or NGOs interested in wetland cultivation to provide inputs or credit to farmers and growing of Irish potatoes should be promoted. Government should consider introduction of subsidies on agricultural inputs for smallholder wetland farmers. Subsided agricultural inputs will make agricultural inputs affordable for the smallholder wetland farmers. Credit can help farmers access agricultural inputs. With access to affordable agricultural inputs, farmers can improve their production consequently improving food security and income. Similarly, growing of Irish potatoes should be promoted. With Mzuzu as a market for Nkhata Bay and other surrounding areas, market for Irish potatoes is assured. The study revealed that Irish potato fetches higher market than any other crops grown in the dimba.

\subsection{LIMITATIONS OF THE STUDY}

This study was not without challenges. The major problem was unavailability of satellite imagery with the desired dates and ability to accurately captures the changes that have occurred. To effectively analyze the extent of stream/river-bank cultivation (wetland cultivation) the study needed satellite images that were captured in the dry season period in the 1986, 1990s, 2000 and 2015 onwards. These years could have represented periods when Malawi was able to produce enough and export surplus; when Malawi started experiencing erratic rain and shortage of food; when people started realizing that erratic rains were here to stay i.e. were persistent and thus started resorting dimba as safety nets and the current situation. However, the only imagery found with the required dates were the 1990 and 2005. This problem limited the land use/cover analysis in this study to the 1990-2005 period than the intended period of 1986 to current years i.e. 2015 onwards.

Similarly, to accurately quantify land use/cover change, high resolution images i.e. IKONOS, Quickbird and SPOT are vital. However, such images are very expensive as such this study settled for Landsat images which are for free but have low resolution. Low resolution of an image makes separation of some land covers very difficult due to spectral similarity. In this case, dimbas (wetland gardens) were spectrally similar to grass. To minimize the confusion, Google Earth was used to identify dimba cultivation areas when re-coding the clusters into classes. 


\section{REFERENCES}

Abbas, I.I., (2012) An assessment of Land Use/ Land Cover Change in a Section of Niger Delta, Nigeria. Frontiers in Science, 3(6), 137-143

Alston, M. (2013). Women and adaptation. Wiley Interdisciplinary Reviews: Climate Change 4(5),351-358.

Barbier, E. B. (2018). Valuing Environmental Functions: Tropical Wetlands. Land Economics,70(2), 155-173.

Behrman, J. A. (2017). Women's land ownership and participation in decision-making about reproductive health in Malawi. Population and Environment, 38(4), 327-344.

Bhaumik, S. K., Dimova, R., \& Gang, I. N. (2016). Is Women's Ownership of Land a Panacea in Developing Countries? Evidence from Land-Owning Farm Households in Malawi. Journal of Development Studies, 52(2), 242-253.

Biging, G.S., Colby, D.R., \& Congalton, R. G. 1999. Sampling systems for change detection accuracy assessment. In R.S. Lunetta \& C.D. Elvidge (eds.), Remote sensing change detection: environmental monitoring methods and applications, London: Taylor and Francis: 281-308.

Bosma, C., Glenk, K., \& Novo, P. (2017). How do individuals and groups perceive wetland functioning? Fuzzy cognitive mapping of wetland perceptions in Uganda. Land Use Policy, 60, 181-196.

Carvalho, S., \& White, H., (1997) Combining the quantitative and qualitative approaches to poverty measurement and analysis: the practice and the potential. World Bank Technical Paper 366

Chidanti-Malunga, J. F. 2009. Wetland Farming and Small-Scale Informal Irrigation in Malawi: The Case of Shire Valley. Ph D Thesis 
Chinsinga, B. 2007.Hedging Food Security through Winter Cultivation: The Agronomy of Dimba Cultivation in Malawi.A Paper read at the Education Development Conference hosted by the National University of Ireland, Galway

Deininger and Xia (2017). Assessing effects of large scale land transfers: Challenges and opportunities in Malawi's estate sector. World Bank, Washington DC Research Institute for Global Value Chains, University of International Business \& Economics, Beijing

Denton, F. (2018). Climate change vulnerability, impacts, and adaptation: 10(2), 10-20.

Dixon, A.B (2005). Wetland Sustainability and The Evolution of Indegenous Knowledge in Ethiopia. The Geographical Journal 174 (4), 306-323.

FAO, 2012: the state of food and agriculture in the world. Closing the Gender Gap. Wowen in Agriculture. Rome

Fisher, M., \& Kandiwa, V. (2014). Can agricultural input subsidies reduce the gender gap in modern maize adoption? Evidence from Malawi. Food Policy, 45, 101-111.

Fisher, M., Chaudhury, M., \& McCusker, B. (2010). Do forests help rural households adapt to climate variability? Evidence from Southern Malawi. World Development, 38(9), 12411250.

Fonji, S.F., \& Taff, G.N., (2014) Using satellite data to monitor land-use land-cover change in North-eastern Latvia. SpringerPlus, 3(3), 61

Foody, G.M. and Mathur, A. 2004a. A Relative Evaluation of Multiclass Image Classification by Support Vector Machines, IEEE Transactions on Geoscience and Remote Sensing 42 (6): 1135-1343.

Government of Malawi (2001). Malawi National Land Policy, Lilongwe, Ministry of Lands and Housing.

Harrigan, J. (2003). U-turns and full circles: two decades of agricultural reform in Malawi 19812000. World Development, 31 (5): 847-863. 
Helliker, K., Murisa,T (2011). Land Struggles and Civil Society in Southern Africa. African World Press, New Jersey

Hulme, M. (1992) 'Rainfall Changes in Africa: 1931-1960 to 1961-1990', Int. J. Climatology 12: 685-699.

IPCC (2013) Summary for policymakers. In: Climate Change 2013: The Physical Science Basis. Contribution of Working Group I to the Fifth Assessment Report of the Intergovernmental Panel on Climate Change (eds Stocker TF, Qin D, Plattner GK, Tignor M, Allen SK, Boschung J, Nauels A, Xia Y, Bex V, Midgley PM), pp. 1-27. Cambridge University Press, Cambridge.

Kaarhus, R. \& Nyirenda, R. (2006). Decentralisation in the agricultural sector in Malawi. Noragric Report no. 32. Aas, Department of International Environment and Development Studies.

Kakota, T., et al (2015). Determinants of household vulnerability to food insecurity: A case study of semi-arid districts of Malawi. Journal of International development, 27, 73 - 84.

Kambewa, D., 2005. Access to and monopoly over wetlands in Malawi. International workshop on African water Laws: Plural Legislative Frameworks for Rural water management in Africa. Johannesburg, South Africa.

Kanyongolo, Fidelis Edge (2005) 'Land Occupations in Malawi: Challenging the Neoliberal Legal Order' in Moyo, Sam and Yeros, Paris (eds.) Reclaiming the Land: The Resurgence of Rural Movements in Africa, Asia and Latin America (London; New York: Zed Books) pp. $118-141$.

Karamba, R.W., and Winters, P.c. (2015) Gender and agricultural productivity: implications of the farm input subsidy program in Malawi. Agricultural Economics, 46, 357 - 374.

Kassie,M., Ndiritu, S.W., and Stage, J., (2014). What determines gender inequality in household food security in Kenya? Application of exogenous switching treatment regression. World development, 56, 153-171.

Kerr, R. B. (2005). Food security in northern Malawi: Gender kinship relations and entitlements in historical context. Journal of Southern African Studies, 31(1), 53-74. 
Kiptot, E., Franzel, S., \& Degrande, A. (2014). Gender, agroforestry and food security in Africa. current Opinion in Environmental Sustainability, 6(1), 104-109.

Kishindo, P. (2004) 'Customary land tenure and the new land policy in Malawi', J. Contemporary African Studies 22(2): 213-225.

Kotze, D. C. (2011). The application of a framework for assessing ecological condition and sustainability of use to three wetlands in Malawi. Wetlands Ecology and Management, 19(6), 507-520.

Laws, S et al (2003) Research for development. London: Sage

Mahenya, O.H (2008). The Role of Wetland Products to Household Income and Food Security in Mvomero District, Tanzania. Phd Dissertation

Mataya, C. S. and E. W. Tsonga. 2001. "Economic Aspects of Development of Agricultural Alternatives to Tobacco Production and Export Marketing in Malawi " in UNCTAD (ed.), Analytical Studies on Trade, Environment and Development, United Nations Conference on Trade and Development, New York and Geneva.

Matchaya, Greenwell. 2009. "Land Ownership Security in Malawi." African Journal of Agricultural Research 4(1):001-013

Mbaya, S. (2002, 24th-25th June 2002). HIV/AIDS and its impact on land issues in Malawi. FAO/SARPN Workshop on HIV/AIDS and Land, Pretoria.

Mbilizi, Margaret Asalele (2013). When a Woman Becomes President: Implications for Gender Policy and Planning in Malawi. Journal of International Women's Studies, 14(3), 148-162

McCusker, B. 2016. Livelihoods and Land Use Produced Together: Evidence from Rural Malawi. Human Geography 9(3): 63-76

McSweeney et al., (2008). UNDP climate change country profiles: Malawi.

Minton and Knottnerus (2008) Ritualized duties: The social construction of gender inequality in Malawi. International Review of Modem Sociology,34(2) 
Msisha, Modechai (1999) 'Land Law in Malawi' in Government of Malawi (1999c) The Final Report of the Presidential Commission of Inquiry on Land Policy Reform, Volume III (Zomba: Government Printer).

Msusa, H. (2011). Sustainable utilization of wetlands for food security: a case study of the Simulemba Traditional Authority in the Kasungu District of Malawi. Journal of Developments in Sustainable Agriculture, 6(1), 86-100.

Mutambikwa A, Muzenda S, Chivinge O, Ellis-Jones J, Riches C and Twomlow S (2000). Participatory Evaluation of vlei utilization and weed problems in communal, resettlement and small scale commercial farming systems of Masvingo and Gutu districts; Report IDG/00/8. Silsoe Research Institute, Silsoe Bedford.

Mwakaje, A. G. (2009). Wetlands, livelihoods and sustainability in Tanzania. African Journal of Ecology, 47(SUPPL. 1), 179-184.

Nabahungu, N. L., \& Visser, S. M. (2011). Contribution of wetland agriculture to farmers' livelihood in Rwanda. Ecological Economics, 71(1), 4-12.

Neukom et al. (2014) Multi-proxy summer and winter precipitation reconstruction for southern Africa over the last 200 years. Climate Dynamics, 42, 2713- 2726.

Nkomwa, E. C., Joshua, M. K., Ngongondo, C., Monjerezi, M., \& Chipungu, F. (2014). Assessing indigenous knowledge systems and climate change adaptation strategies in agriculture: A case study of Chagaka Village, Chikhwawa, Southern Malawi. Physics and Chemistry of the Earth, 67-69, 164-172.

NSO, 2008. Malawi National Statistical Office. Draft census report.

Nyamadzawo (2014) Optimizing dambo (seasonal wetland) cultivation for climate change adaptation and sustainable crop production in the smallholder farming areas of Zimbabwe. 
Oglethorpe, D.R., and Miliadou (2000). Economic valuation of the non-use attributes of a wetland: A case study of Lake Kerkini.Journal of Environmental Planning and Management, 43(6), $755-767$.

Palamuleni, L.G., Annegarn, H.J., and Landmann, T., (2010) Land cover mapping in the Upper Shire River catchment in Malawi using Landsat satellite data. Geocarto International, 25(7), 503-523

Peters, P. E., \& Kambewa, D. (2007). CID Working Paper No. 142: Whose Security? Deepening Social Conflict over 'Customary' Land in the Shadow of Land Tenure Reform in Malawi by Pauline E. Peters and Daimon Kambewa, Center for International Development at Harvard University, (142).

Peters, P.E., 2004a. Informal Irrigation in Malawi's Lake Chilwa Basin: Stream-bank and Wetland Gardens. BASI CRSP Report. JFK School of Government, Harvard University Press.

Phiri, F. 2004. Politics - Malawi: Inching toward that 30 percent. www.ipsnews.net/africa/interna.asp?idnews $1 / 424384$

Rurinda J, Mapfumo P, van Wijk MT, Mtambanengwe F, Rufino MC, Chikowo R, Giller KE (2013) Managing soil fertility to adapt to rainfall variability in smallholder cropping systems in Zimbabwe. Field Crops Research, 154, 211-225.

Schuyt, K. D. (2005). Economic consequences of wetland degradation for local populations in Africa. Ecological Economics, 53(2), 177-190.

Silungwe, C. M. (2005). Customary land tenure reform and development: A critique of customary land tenure reform under Malawi's National Land Policy, Warwick Law School, Dissertation for Master of Laws in Law in Development.

Simon, S., (2014). Fragile ground, contested soil: dynamic of tenure and policy in the Bamenda wetlands. In: The politics of nature and science in southern Africa 2016 (eds Ramutsindela, M., Miescher, G., and Boehi, M.) pp 281 - 304. Namibia Resource Centre and Southern Africa Library. Switzerland. 
Simtowe, F. P. (2010). Livelihoods diversification and gender in Malawi. African Journal of Agricultural Research, 5(3), 204-216.

Tadross M, Suarez P, Lotsch A et al. (2009) Growing-season rainfall and scenarios of future change in southeast Africa: implications for cultivating maize. Climate Research, 40, 147161.

Tiessen R., (2008) Small Victories But Slow Progress, International Feminist Journal of Politics, $10: 2,198-215$

USAID, 2010. "USAID Country Profile, Property Rights and Resource Governance Malawi."

Wang, et al., (2013). Quality analysis of open street map data. 8th International Symposium on Spatial Data Quality, 40(June), 155-158.

Were, et al., (2013) Remotely sensing the spatial and temporal land cover changes in Eastern Mau forest reserve and Lake Nakuru drainage basin, Kenya. Applied Geography 41, 75-86.

WLSA, (2000). A Critical Analysis of Women's Access to Land in the WLSA Countries. WLSA, Harare

Wood, A.P. (2013). People-centred wetland management. In: Wetland management and Sustainable livelihoods in Africa. Taylor and Francis

Zimmerer, K.S. and Bassett, T.J., (2003) Political ecology: An Integrative approach to geography and environment- development studies. New York: The Guiford Press 
